\title{
Verb placement in second language acquisition: Experimental evidence for the different behavior of auxiliary and lexical verbs
}

\author{
JOSJE VERHAGEN \\ Max Planck Institute for Psycholinguistics
}

Received: May 9, 2009 Accepted for publication: June 7, 2010

\author{
ADDRESS FOR CORRESPONDENCE \\ Josje Verhagen, University of Utrecht, P.O. Box 80140, Utrecht 3508 TC, The Netherlands. \\ E-mail: J.Verhagen@uu.nl
}

\begin{abstract}
This study investigates the acquisition of verb placement by Moroccan and Turkish second language (L2) learners of Dutch. Elicited production data corroborate earlier findings from L2 German that learners who do not produce auxiliaries do not raise lexical verbs over negation, whereas learners who produce auxiliaries do. Data from elicited imitation and sentence matching support this pattern and show that learners can have grammatical knowledge of auxiliary placement before they can produce auxiliaries. With lexical verbs, they do not show such knowledge. These results present further evidence for the different behavior of auxiliary and lexical verbs in early stages of L2 acquisition.
\end{abstract}

Most research on second language (L2) acquisition looks either at production or processing, and comparisons between the two domains are rare. The study of verb placement is not exceptional in this respect. Scholars have investigated how L2 learners acquire verb placement by looking at spontaneous or elicited production data, taken from interviews or production tasks. Such studies have typically led to the characterization of the acquisition process as a series of successive stages, each with their own internal logic and increasing similarity to the grammar of the target language (Cancino, Rosansky, \& Schuman, 1978; Clahsen, 1983). In contrast, researchers have studied how L2 learners deal with verb placement in controlled processing experiments (Beck, 1998; Eubank \& Grace, 1996). In the latter studies, not much information is generally available about learners' production, apart from measures taken from judgement or translation tasks that serve to group learners according to proficiency.

A robust finding in $\mathrm{L} 2$ research on verb raising languages is that light verbs such as modal and auxiliary verbs precede negation from their first emergence, whereas lexical verbs initially follow negation (Clahsen, 1988; Hawkins, 2001; Haznedar \& Schwartz, 1997; Meisel, 1997; Parodi, 2000; Tomaselli \& Schwartz, 
1990). In particular, auxiliaries have been claimed to fulfill a crucial role: unlike lexical verbs, such verbs lack a clear lexical meaning of their own and occur with nonfinite lexical verbs (past participles). Various researchers have argued that, due to these properties, such verbs play an important role in the acquisition of verb placement. Vainikka and Young-Scholten (1996a, 1996b) analyzed longitudinal production data from Korean and Turkish learners of German and found that these learners only started to (optionally) raise verbs over negation and adverbs after the acquisition of subject-verb agreement, which was typically instantiated after the acquisition of auxiliary verbs. They also observed that verb placement with auxiliaries was more targetlike than with lexical verbs. Becker (2005) and Dimroth (2008) found that Italian and Russian learners of German only raised lexical verbs over negation after they had acquired the auxiliary verb haben. They concluded that the acquisition of auxiliary verbs constitutes a major step toward targetlike verb placement in L2 German.

The observation that auxiliary verbs are important for the acquisition of verb placement is solely based on evidence from production data. As noted by several L2 researchers, however, there are clear drawbacks to relying on production data alone as a measure of learners' linguistic competence (Epstein, Flynn, \& Martohardjono, 1996; Grondin \& White, 1996; Grüter, 2005/2006; White, 1992). Beginning L2 learners often use formulas that do not yet reflect the application of a rule, but are taken over from the input as unanalyzed forms. The inclusion of such forms can easily lead to an overestimation of learners' linguistic knowledge. At the same time, however, linguistic knowledge might be present in the L2 learners' mental grammar that does not yet make its way into production. Grondin and White (1996, p. 5) noted in this respect that "one should be wary ... that if something does not occur in production, it is absent from the grammar." There is evidence that learners can have linguistic knowledge of a particular linguistic phenomenon before they can use this knowledge for production (Beck, 1998; Grüter, 2005/2006; Naiman, 1974). An important purpose of the present study is therefore to investigate L2 verb placement by considering data from different experimental techniques, including methods that are assumed to tap into linguistic competence more directly than (spontaneous or elicited) production. The study builds on the idea that auxiliaries lead to the acquisition of targetlike verb placement in L2 German and investigates whether this finding can be confirmed for L2 Dutch. Dutch is typologically similar to German, but it has thus far not often been investigated in L2 studies on verb placement. In particular, the study addresses the question whether there is evidence for the important role of auxiliaries when data other than production data are investigated: controlled data from an elicited imitation and a sentence processing task. Do learners who produce auxiliaries behave differently from learners who do not produce auxiliaries in such tasks? Do learners show linguistic knowledge in imitation and processing that is not yet visible in their production?

The paper is organized as follows: the next section presents an overview of earlier studies on the production and processing of verb placement in L2 acquisition. Subsequently, the main typological properties of the languages under study are outlined, and the study's research questions and methodology are described. Three types of task were conducted: elicited production, elicited imitation, and sentence matching. The results from the elicited production tasks will be described first. 
The main aim of the study, then, is to compare these data with elicited imitation and sentence-matching data from the same learners. Finally, the main findings from the different tasks will be summarized and evaluated.

\section{BACKGROUND}

\section{Production studies}

There is ample evidence from L2 production studies that learners of verb-raising languages initially place lexical verbs in a position following negation, resulting in ungrammatical structures. The development towards a targetlike placement of such verbs is gradual and there is often a long phase at which verbs can follow and precede negation. With auxiliaries, in contrast, verb placement is targetlike from the time such verbs first emerge: these verbs consistently precede negation and there is no stage in the acquisition process at which auxiliary verbs follow negation (Meisel, 1983; Parodi, 2000; Schwartz \& Sprouse, 1996; Vainikka \& Young-Scholten, 1996a, 1996b). ${ }^{1}$ There is an extensive literature on the acquisition of verb raising: studies have looked at raising past negation and adverbs, raising of different types of verb, and in various source and target language combinations (Eubank, 1993/1994; Schwartz \& Sprouse, 1996; Vainikka \& Young-Scholten, 1996a, 1996b; White, 1991, 1992). As the focus of the current study is on the acquisition of auxiliary and lexical verb placement in relation to negation in a Germanic language (Dutch), the following summary is restricted to studies on L2 German that have differentiated between auxiliary and lexical verbs.

For L2 German, it has been proposed that auxiliary verbs play a crucial role in the acquisition of verb placement such that the acquisition of auxiliaries would lead to targetlike placement of all verbs. Vainikka and Young-Scholten (1996a, 1996b) found that lexical verbs are initially placed behind negation in the L2 productions from Turkish and Korean learners of German. No auxiliary verbs are used at this stage. To explain this pattern, the authors propose that only bare verb phrases can be projected at this early stage. At the next stage, learners learn to project an underspecified functional projection (FP), which provides a position for raised verbs as well as modals and auxiliaries. Because FP is still underspecified for tense and agreement at this stage, verb raising is optional: verbs can precede as well as follow negation. Finally, learners project an AgrP: they now use modals and auxiliaries, and verb placement of lexical verbs is largely correct. Of importance, Vainikka and Young-Scholten assume that this final stage is triggered by "the productive usage of a functional element, particularly one lacking in semantic content such as the auxiliary" that indicates the acquisition of a syntactic position for finite verbs (Vainikka \& Young-Scholten, 1996b, p. 168). That is, they assume that the acquisition of auxiliary verbs enables L2 learners to create a syntactic position for finite verbs that can then be used as a landing site for raised lexical verbs.

The idea that auxiliaries are important for the acquisition of verb placement has also been put forth in a series of studies that take a functional perspective on L2 acquisition (Becker, 2005; Dimroth, 2008). Becker (2005) investigated naturalistic longitudinal data of three Italian learners of German and found, like Vainikka and Young-Scholten (1996a, 1996b), that three stages characterize the acquisition of 
verb placement in L2 German. At the first stage, only lexical verbs are produced and such verbs consistently follow negation in negated sentences. Following other authors (Bernini, 2003; Klein, 1998), Becker explains this ordering in terms of a semantic principle: semantic scope marking. According to this principle, the negator precedes the elements in a sentence over which it has scope, that is, the elements that it semantically affects. Thus, in a sentence such as Mein Vater nicht schlafen "My father not sleep," nicht precedes schlafen because the verb is in its semantic scope domain (Becker, 2005, p. 287). ${ }^{2}$ The next stage is characterized by the acquisition of auxiliary verbs. These verbs differ from lexical verbs in that they do not have a clear meaning of their own, but only mark aspect. Crucially, auxiliary verbs appear in a targetlike position from the start in L2 acquisition. Becker explains this in terms of these verbs' semantic properties: due to their lack of clear semantic content, they fall outside the scope of negation. More precisely, in a German sentence such as Er hat nicht lese "He has not read" (Becker, 2005, p. 293) negation follows the auxiliary verb because the negator only has scope over the lexical verb lese "read." Becker finds that the targetlike placement of auxiliaries is extremely consistent: auxiliaries never follow negation in her corpus. Moreover, auxiliary verbs consistently appear with correct finiteness marking. Becker attributes this finding to the auxiliaries' co-occurrence with forms that are clearly marked for nonfiniteness (i.e., past participles). The co-occurrence of a clearly finite form (the auxiliary) and an overtly marked nonfinite form (a past participle) would make the finite/nonfinite distinction transparent to the L2 learner. Consequently, at the final stage, learners learn to extend finiteness marking to all verbs: they start to produce finite lexical verbs and raise such verbs over negation. This results in targetlike sentences such as Er liest nicht "He reads not," in which the negator follows the lexical verb. In such utterances, the preference for transparent scope relations is given up in favor of a grammatical rule of the target language according to which finite verbs must be placed in a higher position in the clause. The transition from a semantically based system to a syntactic system is not a one-step development, however, and Becker notes that it is not uncommon that advanced learners may "backslide" into constructions typically used at earlier stages.

In short, previous evidence from production studies suggests that auxiliaries play an important role in the acquisition of verb placement. In a syntactic-oriented, "structure-building" approach, such verbs are assumed to create a syntactic position to which finite, lexical verbs can raise. In functionalist studies, auxiliaries are assumed to precede negation due to their "thin" semantics and trigger finiteness marking due to their co-occurrence with overtly marked nonfinite forms (i.e., past participles). In the current study, a number of predictions for L2 Dutch will be derived from the idea that auxiliaries fulfill a special role in the acquisition of verb placement in production, imitation, and processing. Before these predictions will be outlined, the next section addresses the main outcomes of studies that have looked at verb placement in L2 processing.

\section{Processing studies}

Very few studies on verb placement in L2 processing have appeared, and without exception they have focused on the question of whether verb morphology and verb 
raising are interrelated in L2 acquisition. The reason for investigating this relation is that, within universal grammar (UG), a relation is assumed between finiteness and verb raising: finite verbs should occur in a raised position and nonfinite verbs should appear in a nonraised position (Chomsky, 1995). More specifically, verbs can have strong or weak verb features, and this has consequences at the syntactic level: in verb raising languages like Dutch, German, and French, verbs with strong verb features raise overtly to the functional category inflection for their features to be checked, but verbs with weak inflection features raise covertly. There have also been attempts to relate the complexity of the verbal agreement paradigm to verb raising (Rohrbacher, 1994; Vikner, 1995) by defining the "strength" of the agreement paradigm in terms of overtly detectable morphological properties. For example, Rohrbacher (1994) considered agreement as "strong" when the first and second person are distinctively marked from each other, from the third person and from the infinitive, in at least one number (singular or plural) of one tense of regular verbs.

In L2 acquisition studies, researchers have looked at the possible relation between finiteness and verb raising, that is, whether L2 learners place finite verbs in a raised position, but nonfinite forms in a nonraised position. Such a contingency between finiteness and verb raising could be taken as evidence that UG is still accessible to L2 learners. A random placement of finite and nonfinite forms in raised and nonraised position, in contrast, would indicate that UG can no longer be accessed.

Verb placement with respect to adverbs rather than negation has typically been used to investigate verb raising (and its relation to finiteness) in L2 processing. Within a UG-based framework, the same relation has been assumed between verb raising, on the one hand, and adverbs and negation, on the other hand: the finite verb is assumed to raise to a higher position and leave negation and adverbs behind. ${ }^{3}$ Although the questions asked in these studies differ from the ones investigated here, the main outcomes of processing studies on the acquisition of verb raising in sentences with adverbs are relevant for the current purposes, so they are summarized below.

In a reaction-timed study with English learners of German, Beck (1998) tested the two conflicting views on verb raising in L2 acquisition: (a) the acquisition of finiteness leads to verb raising versus (b) finiteness does not lead to verb raising. She performed a sentence-matching task, in which participants were asked to judge two visually presented sentences as being the same or different. In such a reaction-timed task, the time it takes participants to make this judgement is measured and taken as an indication of the sentences' grammaticality (Chambers \& Forster, 1975; Duffield \& White, 1999; Freedman \& Forster, 1985). The rationale behind this measurement is that native speakers take less time to match two identical grammatical sentences than two identical ungrammatical sentences. Because the task will be described in more detail below, it suffices to point out here that the task measures the processing of grammaticality and that it is covert. Participants are not directly asked for their judgements about grammaticality, but about whether two sentences are the same. When applied to L2 learners, the assumption is that longer times reflect ungrammaticality for the learner in the same way as for native speakers, with, as a major difference, that what is 
grammatical for the learner need not be grammatical in the target language and vice versa.

The task used by Beck contained German sentences in which a verb either was or was not raised over an adverb, as exemplified in (1a) and (1b).

(1a) Der Vater liest selten die Zeitung "The father reads seldom the paper"

(1b) *Der Vater dann schreibt ein Lied "The father then writes a song"

These sentences were presented to native speakers and English learners of German. The learners had been subdivided into different groups on the basis of their scores on a written translation task: (a) learners who used agreement versus learners who did not and (b) learners who used subject-verb inversion versus learners who did not. ${ }^{4}$ The results showed that both agreement groups responded equally fast to sentences with raised and nonraised verbs. Surprisingly, the no-inversion group responded faster to raised than nonraised verbs, whereas no effect was found for the inversion group. To explain the effect for the no-inversion group, Beck assumed that these learners lacked FPs and represented the raised sentences as English-type sentences with heavy NP shift. ${ }^{5}$ She also assumed that the agreement and inversion groups did not demonstrate a processing preference because verb raising was optional for these learners.

Eubank and Grace (1996) performed a similar study in which they investigated the processing of verb raising by native speakers and Chinese learners of English (both languages lack verb raising). The authors found a grammaticality effect for native speakers: processing times were shorter for nonraised verbs as in "Mary often watches TV" than for raised verbs as in "*Mary watches often TV." For the advanced Chinese learners of English, who were assumed to have acquired subject-verb agreement based on their scores on an online translation task, no differences in response times were found. On the basis of this result, the authors conclude that verb raising is optional for these learners, even though their L1 does not have verb raising and despite learners' relatively advanced level of acquisition.

Taken together, the results of these studies do not support the idea of a relation between agreement and verb raising in L2 acquisition. The lack of effects might also be due to a number of methodological problems, however. First, the two studies seem to have compared "apples and oranges," namely, the production of agreement/inversion with the processing of verb raising. It is well established in the L2 literature that learners may show knowledge in comprehension or processing before they can use this knowledge for production (Epstein et al., 1996; Krashen $\&$ Terrell, 1983). For this reason, it may be problematic to compare production and processing to find out whether two linguistic phenomena are related. It is conceivable that the learners in Beck's study had knowledge of agreement or inversion that they were not yet able to engage in production. A second problem is that no production data on verb raising were collected, making it hard to interpret the results. In Beck's study, for example, we cannot be sure that "optional verb raising" in the advanced group did not result from conflating two learner groups: a group that used verb raising in production and a group that did not. To avoid such problems, the present study looks at one linguistic phenomenon (verb raising over negation) in data from different "domains": production, imitation, and processing. 
Verhagen: Verb placement in second language acquisition

\section{VERB PLACEMENT AND NEGATION IN DUTCH, MOROCCAN ARABIC, AND TURKISH}

Before the study's research questions and predictions are presented in the next section, a brief summary of the main typological properties is given below for the three languages under study.

\section{Dutch}

Dutch has verb raising and it is a verb-second language, which means that finite verbs must appear in second position in main clauses. This can be seen in (2), where the finite verb leest "reads" has been raised over the free negation morpheme niet "not."

(2) Jan zwemt niet in de rivier

John swim-3sg not in the river

"John doesn't swim in the river"

Nonfinite verbs do not raise and remain in final position. Thus, such verbs occur to the right of negation in negated sentences with modal and auxiliary verbs:

(3) Peter heeft niet de afwas gedaan

Peter has not the dishes do- $p p$

"Peter hasn't done the dishes"

In subordinate clauses, finite verbs do not raise, but they remain in final position (i.e., Ik denk dat Peter nooit de afwas doet "I think that Peter never the dishes does"). In addition, Dutch allows scrambling of direct and indirect objects that can appear to the left or the right of negation and adverbs. For example, in (3) above, the direct object de afwas may also precede the auxiliary: Peter heeft de afwas niet gedaan. ${ }^{6}$

\section{Moroccan Arabic}

Moroccan Arabic has verb-subject-object (VSO) as its basic word order (Ennaji, 2005). SVO order is also used, but this order is restricted to specific discourse conditions, for example, when the subject is focused. Finite verbs and even whole verb complexes are raised: strong features attract the verb from head to head until the entire verbal complex (including auxiliary verbs, if present) is raised to Agr, where person and number features are checked (Ouhalla, 1994). The example in (4) illustrates a negated declarative sentence and shows that negation is expressed

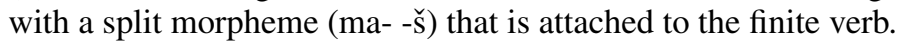

(4) Ma- ka- n- šuf- hom -š koll nhar

neg- dur- 1sg.imperf- see- them -neg every day

"I don't see them every day"

(Harrell, 1962, p. 152)

In sentences with auxiliaries, the negative morphemes $m a$ - and $-\check{s}$ are attached to the auxiliary:

(5) Ma- ġadi- -š ne- kteb -lek gedda

neg- fut- -neg 1sg.imperf- write -ind.obj.2sg tomorrow

I am not going to write to you tomorrow" (Van de Craats \& Van Hout, 2010, p. 480) 


\section{Turkish}

Turkish is a pro-drop language with SOV as its basic word order, but scrambling also occurs, depending on information structure (Erguvanl1-Taylan, 1984; Kornfilt, 1997). Turkish does not have overt verb raising. Instead, each of the verb suffixes projects a functional head and the verb moves through these heads to AgrP (Haznedar, 1997). This movement is vacuous, because it does not change the surface order of clausal elements: the negative suffix follows the verb root but precedes tense and agreement morphemes and the finite verb is placed in final position. The following sentence illustrates that verbal predicates are marked with the negation suffix $-m A$ :

(6) Hasan kitab-1 oku-ma-d1

Hasan book-acc read-neg-past

"Hasan didn't read the book"

(Kornfilt, 1997, p. 123)

Turkish has two other ways to express negation: (a) substantive predicates are negated by the negative copula değil "not," which is also marked by inflectional suffixes, and (b) existential and possessive predicates are negated with the negative predicate yok "not existent." In (7) and (8) the use of de ğil and yok are illustrated. ${ }^{7}$ See Erguvanl1-Taylan (1984) and Tura (1981) for a detailed analysis of Turkish negation.

(7) (Ben) hasta değil-di-m

(I) sick neg.cop-past-1 sg

"I was not sick"

(Kornfilt, 1997, p. 124)

(8) (Ben-im) araba-m yok-tu

(I-gen) car-1sg neg.exist-past

"I had no car"

(Kornfilt, 1997, p. 125)

\section{RESEARCH QUESTIONS}

The aim of this study is to investigate the acquisition of verb placement in negated sentences in L2 Dutch, using various elicitation tasks. As a first step, production data will be analyzed to test whether the acquisition stages that were found for (Italian) L2 learners of German also hold for Moroccan and Turkish learners of Dutch. The results of this analysis mainly serve to set up a comparison with data from controlled language tasks that are less subject to performance factors than production and hence can be assumed to tap into learners' linguistic competence more directly. Two groups of learners will be compared: a -AUX group consisting of learners who did not produce the Dutch auxiliary hebben "have" and a +AUX group consisting of learners who did. There are two research questions.

1. Do the two groups differ in their placement of verbs in negated sentences in production?

2. How do the groups deal with verb placement in elicited imitation and processing? 
A number of predictions can be derived from these questions. First, based on Becker's findings for L2 German, the -AUX group is expected to place lexical verbs in a position following negation in production, because they have not yet acquired auxiliary verbs and are thus not expected to use verb raising. The +AUX group is predicted to raise lexical verbs over negation. Verb raising may still coincide with no raising in this group, however, given that targetlike verb placement is assumed to develop gradually. In auxiliary sentences, the +AUX group is expected to place auxiliaries in a correct position with respect to negation in a consistent manner. As for imitation and processing, earlier research makes no clear predictions. If learners have a preference for the structures they produce themselves, the -AUX group can be predicted to prefer lexical verbs in a position following negation. Similarly, it can be hypothesized that the +AUX group prefers both lexical verbs and auxiliaries to precede negation. The preferred pattern for auxiliary verbs for learners in the -AUX group remains an open question: these learners do not yet use such verbs in their own speech, so it is difficult to predict whether they will show a preference for auxiliaries to precede or follow negation, or no preference at all.

Learners may also prefer raised or nonraised verbs, dependent on how verb placement and negation are expressed in their native language. Opposing views have been put forward in the L2 literature as to whether verb raising can be transferred from learners' first language (L1). Researchers have argued for full transfer of FPs, implying that learners' syntactic knowledge of the L1 presents the initial state of L2 acquisition (Schwartz \& Sprouse, 1996). Under such a view, the Moroccan learners would have less trouble acquiring the placement of Dutch verbs than the Turkish learners, because Moroccan Arabic has verb raising, but Turkish has not. Other theories hold that learners cannot transfer higher FPs above the verb phrase (Vainikka \& Young-Scholten, 1996a, 1996b). If we assume that there is no transfer of functional categories, no difference is predicted between the Moroccan and Turkish learners with respect to the acquisition of verb raising. For the current study, it remains an open question whether the Moroccan learners have an advantage in acquiring verb raising. If so, this would constitute evidence that higher functional categories can be transferred into the L2. Except for differences in verb raising, the two native languages also differ in whether they have auxiliary verbs. Moroccan Arabic has a large set of auxiliary verbs marking tense and aspect, but Turkish lacks such verbs. Thus, if the mere existence of auxiliaries in learners' L1 is a facilitating factor in acquiring such verbs in the L2, Moroccan learners of Dutch can be predicted to have fewer problems with the acquisition of auxiliaries than Turkish learners.

\section{THE STUDY}

\section{Participants}

Fifty-five Moroccan learners and 46 Turkish learners of Dutch participated in the study. These learners were recruited at schools in The Netherlands where they took Dutch courses that are obligatory for new immigrants. They received about $9 \mathrm{hr}$ of teaching per week but the main class activities involved content-driven 
exercises such as role play, and almost no explicit grammar instruction was given. All participants had a beginning level of acquisition: they were at Level 1 or 2 out of five proficiency levels, as indicated by school tests. ${ }^{8}$ They were poorly educated in their home country: most learners had only been at primary school, some of them had passed a few years at secondary school, but none of them had studied at university. The average number of years of schooling in their home country was 9 years for the Moroccan and 7.6 years for the Turkish learners. Five Moroccan and 3 Turkish learners were illiterate in their native language and had received between 0 and 3 years of education only. ${ }^{9}$ Length of residence in the Netherlands varied across participants, with a mean of 3.6 and 5.3 years for the Moroccan and Turkish learners, respectively. For both language groups, ages ranged between 19 and 42, and the average age was 28. Most of the Turkish learners were monolingual, but 13 learners reported (rudimentary) knowledge of English, 2 learners spoke a little bit of German and 1 learner reported to have some knowledge of French. As for the Moroccan learners, 38 learners had some knowledge of French (varying proficiency levels, mostly in oral language only), 4 had a good command of Spanish, and 16 spoke Berber in a native or near-native manner. However, with respect to the relevant typological properties, Berber does not seem to differ significantly from Moroccan Arabic. ${ }^{10}$

In addition to these learners, a control group of 28 Dutch native speakers carried out the sentence-matching task. ${ }^{11}$ A subset of these (10 learners) also carried out the production tasks. ${ }^{12}$ All of the native speakers were recruited at secondary vocational education ${ }^{13}$ and thus were also relatively poorly educated. They ranged between 16 and 21 years in age, with an average age of 18 .

\section{Tasks: What they measure and how}

Two types of production task were used to elicit negated utterances: film-retelling and picture story tasks. To test learners' processing of lexical verb and auxiliary placement in negated sentences, a sentence-matching task was used. As we have seen above, participants judge two sentences as being the same or different in such a task and the time it takes them to give this judgement is measured. On the assumption that grammatical structures are processed faster than ungrammatical ones, participants' processing times are taken as an indication of a sentence's grammaticality (for a given participant). In addition to these tasks, an elicited imitation task was used. In elicited imitation, participants repeat sentences that are manipulated for linguistic structure. These sentences can be grammatical or ungrammatical, and ideally, they are constructed in such a way that they cannot easily be imitated verbatim, that is, they should be of sufficient length not to be stored as chunks. The rationale behind the task is that, because the sentences are too long to be stored as chunks in memory, they have to be reconstructed by participants. ${ }^{14}$ For (beginning) L2 learners, the task has proven useful in investigating learners' linguistic knowledge: learners make changes to the stimuli sentences and these changes are assumed to reflect subconscious, abstract grammatical knowledge (Munnich, Flynn, \& Martohardjono, 1994). It has also been shown that elicited imitation can reflect grammatical knowledge that learners cannot (yet) actively use (Naiman, 1974). It cannot be excluded that participants might sometimes repeat 
sentences verbatim, however. Also, unlike in a sentence-matching task, where participants need not produce language themselves but only give motor responses, language production (repetition) takes place in elicited imitation. For these reasons, it seems safe to assume that both tasks can tap into linguistic knowledge that is not available for active language production (creation), but that such knowledge is more likely to show up in sentence matching. Thus, the three tasks used in this study form a scale representing the degree to which "active" linguistic knowledge is involved: elicited production $>$ elicited imitation $>$ sentence matching. Although the ability to actively produce a certain form is necessary to be able to use this form in a film retelling or picture story task, more "passive" knowledge can do the job in elicited imitation, and this is even more clear in sentence matching, where participants need not produce any language themselves.

\section{Production tasks}

Four production tasks were used: a 10-min fragment from a silent movie (Charlie Chaplin's "Modern Times"), an animated movie ("The finite story"; Dimroth, 2005), and two picture stories. The first film-retelling task aimed at the elicitation of auxiliaries and negation and the second one mainly aimed at eliciting negation. Both films were cut into small fragments and participants retold what had happened immediately after they had watched a fragment. Altogether, the films elicited between 4 and 10 negated utterances from the native speakers (mean $=5.8$ ). The picture stories depicted simple events and so-called "target events" to increase the likelihood that participants would produce auxiliary verbs. More precisely, pictures like the following were included where it can be concluded from the last picture that the dog has eaten the cake, even though the eating event itself is not depicted. By showing the resultant state of some event without giving participants the opportunity to describe the event as ongoing (i.e., De hond eet de taart "The dog is eating the cake"), optimal conditions for the use of auxiliaries were created.
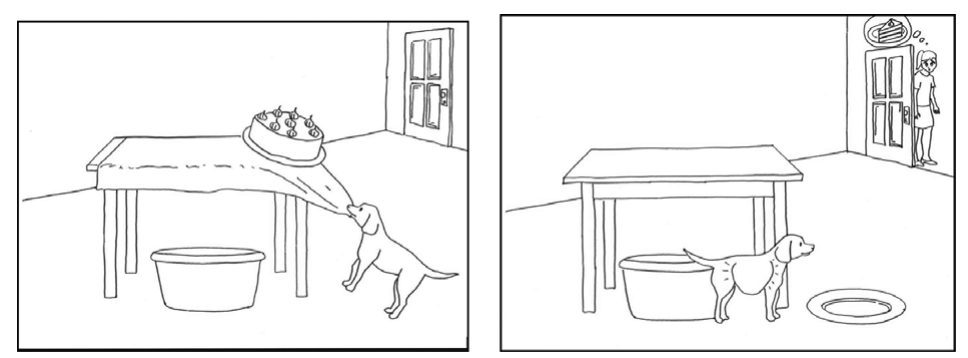

Note, however, that the use of an auxiliary is never obligatory in such contexts, because speakers may always describe the story from a different perspective and use a passive sentence (i.e., De taart is opgegeten door de hond "The cake has been eaten by the dog") or a construction expressing the resultant state (i.e., $D e$ hond zit vol "The dog is full"). 


\section{Elicited imitation task}

In elicited imitation, participants repeat sentences of which the grammatical structure is manipulated. The rationale behind this task is that the sentences are too long to be stored as "chunks" in memory, and therefore, participants have to reconstruct them on the basis of their own linguistic knowledge. Because such changes are typically made subconsciously, participants' imitations are assumed to reflect abstract grammatical knowledge or linguistic competence (Munnich et al., 1994). Although there has been a debate in the literature on the validity of this task (Bley-Vroman \& Chaudron, 1994; Markman, Spilka, \& Tucker, 1975), most researchers currently agree that the task is reconstructive, although there are clear interacting variables such as sentence length, time pressure, and the instruction given to participants (Erlam, 2006; Vinther, 2002).

The current task contained four sentence types that together presented two variables with two levels each: "negation" (postverbal vs. preverbal) and "verb type" (lexical verb vs. auxiliary):

\section{LEX-NEG: De minister praat niet over het grote probleem "The minister talks not about the big problem" \\ *NEG-LEX: *De minister niet praat over het grote probleem "The minister not talks about the big problem" \\ AUX-NEG: De minister heeft niet over het probleem gepraat "The minister has not about the problem talked" \\ *NEG-AUX: *De minister niet heeft over het probleem gepraat "The minister not has about the problem talked"}

There were 3 items per type, resulting in 12 experimental items. ${ }^{15}$ Twenty-four filler items were included to distract learners' attention from the target structures. Half the filler items were ungrammatical and the other half were grammatical so that the overall the grammatical/ungrammatical ratio was 1:1. The fillers involved (violations of) subject-verb inversion and (violations of) subject-verb agreement marking, as can be seen below:

$\begin{array}{ll}\text { Inversion: } & \begin{array}{l}\text { Elke dag rookt de oude meneer een sigaret } \\ \text { "Every day smokes the old man a cigarette" }\end{array} \\ \text { *No inversion: } & \begin{array}{l}\text { *Elke dag de oude meneer rookt een sigaret } \\ \text { "Every day the old man smokes a cigarette" }\end{array} \\ \text { Agreement: } & \begin{array}{l}\text { De man geeft een mooi cadeau aan de directeur } \\ \text { "The man gives a nice present to the director" }\end{array} \\ \text { *No agreement: } & \text { *De man geven een mooi cadeau aan de directeur } \\ \text { "The man give a nice present to the director" }\end{array}$

Item frequency and sentence length were kept constant across all experimental and filler items. To control for frequency, only nouns and verbs from a combined frequency list of Dutch were used. ${ }^{16}$ All verbs were regular, and all items contained eight or nine words and 12 or 13 syllables. In order to keep sentence length equal across the different types, the auxiliary items often lacked an adjective or noun 
that was present in the corresponding lexical verb items. Although this was not considered ideal, the alternative of comparing long auxiliary items to shorter lexical verb items was considered even less desirable (see Appendix A for a list of items).

Four counterbalanced, pseudorandomized lists were constructed. To avoid ordering effects, an additional version was constructed for each list in which the order of presentation of the items was varied (i.e., the second list started with the second half of the first list, followed by the first half). All lists began with the same two warm-up items. The entire task was administered in two sessions. Half of the participants performed the lexical verb session first, whereas the other half carried out the auxiliary session first. To reduce carryover effects, the production tasks were administered to the participants between these two sessions.

All items were prerecorded by a female native speaker of Dutch in a soundproof cabin and played to the participants via earphones. Participants were instructed to start their repetition only after they had listened to the entire sentence, and they were kept ignorant about the ungrammaticality of half of the items. When participants were not able to imitate the stimulus for some reason, it was played again with a maximum of three repetitions.

\section{Sentence matching}

In a sentence-matching task, two sentences are presented to participants, and the time it takes participants to judge whether these sentences are the same or different is measured (Chambers \& Forster, 1975; Duffield \& White, 1999; Duffield, White, Bruhn de Graviot, Montrul, \& Prévost, 2002; Freedman \& Forster, 1985). The task is based on the finding that participants respond more quickly to grammatical sentence pairs like those in (9) than to ungrammatical pairs like those in (10) (Freedman \& Forster, 1985):

(9) Dogs growl

Dogs growl

(10) *Growl dogs

*Growl dogs

The faster response time to (9) has been taken as evidence that the available structure in the grammatical sentences facilitates the same/different choice. A participant's reaction time to a given pair can thus be considered a function of the grammaticality of the paired sentences. Of importance, such a facilitation of grammatical over ungrammatical sentences typically holds for native speakers; the distinction between grammaticality and ungrammaticality becomes less clearcut when the task is applied to language learners. Previous research has shown, however, that faster reaction times also reflect grammaticality for the learner, so the sentence-matching task has been considered a helpful tool for finding out what is grammatical in the L2 learner's grammar at a given point in development (BleyVroman \& Masterson, 1989). That L2 learners have a different mental grammar entails that they may show facilitation for structures that are ungrammatical in the L2 as well as inhibition for structures that are grammatical. 
The task was auditory, in contrast to earlier sentence-matching tasks that were all performed in a visual mode. Piloting showed that auditory presentation of the stimuli yielded a grammaticality effect among native speakers, enabling investigations into the processing of grammaticality in populations that do not have (automatized) reading skills, such as children and beginning L2 learners. In the current study, auditory stimuli were used because participants were not proficient readers in the $\mathrm{L} 2$.

The experimental items were similar to those in the elicited imitation task, with the exception that proper names instead of full nouns were used as sentential subjects. The reason for this was a pragmatic one: only a few animate nouns appeared to be frequent enough in the target language to be used. Another exception is that the task contained only plural subjects of the type "John and Anne." This was done in order to obtain sentences that were as similar as possible to the structures that learners produced themselves. More precisely, the production data had shown that nonraised verbs overwhelmingly ended in -en instead of in a correct agreement suffix. To ensure that possible effects in the sentence-matching data were not due to an interaction between verb placement and agreement marking rather than to verb placement alone, only plural verb forms ending in -en were used (as plural verbs are homophonous with infinitives in Dutch).

The same conditions were used as in the elicited imitation task. These are repeated below. Note that sentences were presented in pairs such that the first sentence was presented twice, the second sentence was presented twice, and so on.

\begin{tabular}{|c|c|}
\hline LEX - NEG: & $\begin{array}{l}\text { Anna en Frank koken niet in de keuken } \\
\text { "Anna and Frank cook not in the kitchen" }\end{array}$ \\
\hline$*$ NEG-LEX: & $\begin{array}{l}\text { *Anna en Frank niet koken in de keuken } \\
\text { "Anna and Frank not cook in the kitchen" }\end{array}$ \\
\hline AUX - NEG: & $\begin{array}{l}\text { Anna en Frank hebben niet in de keuken gekookt } \\
\text { "Anna and Frank have not in the kitchen cooked" }\end{array}$ \\
\hline *NEG-AUX: & $\begin{array}{l}\text { *Anna en Frank niet hebben in de keuken gekookt } \\
\text { "Anna and Frank not have in the kitchen cooked" }\end{array}$ \\
\hline
\end{tabular}

Six pairs per condition were presented, which resulted in a total of 24 experimental items. There were also 36 filler pairs, resulting in an overall experimental/filler ratio of $1: 1.5$. The sentences in a filler pair differed either lexically or syntactically from each other, and these differences occurred at different positions within the sentence (initial-medial-final). All experimental items occurred as matching pairs, and of the filler pairs, 30 were nonmatching and 6 were matching, resulting in an overall matching/nonmatching ratio of 1:1. Half of the filler sentences were grammatical and the other half were ungrammatical. Thus, equal numbers of "grammatical" versus "ungrammatical" pairs and "matching" versus "nonmatching" pairs were used to prevent any biases in the experiment. For an overview of the items, see Appendix B.

Four counterbalanced, pseudorandomized lists as well as four additional lists in which the stimuli order was varied were constructed. Each list started with the same two filler pairs. The stimuli were prerecorded in a soundproof cabin by the same female native speaker of Dutch who read the stimuli for the elicited imitation 
task, and they were implemented in the software program NESU (Baumann, Nagengast, \& Wittenburg, 1992). In the presentation during the experiment, a 150 -ms break occurred between the two sentences of a pair, and reaction times were measured from the offset of the second sentence. At this point, a picture on the computer screen indicated that participants could give their responses. It is important that yes/no questions were presented after each experimental item (after participants had given their responses) and at variable intervals after a third of the filler items. These questions served as a measure to find out whether participants stayed "online" during task performance. ${ }^{17}$ Participants responded to the questions by pressing the "different" button for "no" and the "same" button for "yes." Prior to the experiment, participants received oral instructions and performed a short training session. A self-paced break was allowed after participants had performed half of the task.

\section{General procedure}

All participants carried out the tasks individually in a quiet room at their schools. The order of task presentation was as follows: film retelling 1 ("Modern Times"), elicited imitation (Session 1: lexical verbs or auxiliaries), film retelling 2 ("Finite Story"), sentence matching, elicited imitation (Session 2: lexical verbs or auxiliaries), picture stories. The entire session lasted approximately $1.5 \mathrm{hr}$, and at the end of the session participants were paid 10 euros. All participants completed the tasks in one session.

\section{RESULTS FOR PRODUCTION}

\section{Two learner groups}

First of all, learners were divided into two groups on the basis of whether or not they produced auxiliary verbs in the production tasks. Thirty-one learners out of all the 55 Moroccan learners produced at least one auxiliary, and 25 out of all the Turkish learners did. From now on, these learners will be referred to as the +AUX group and those learners who did not use auxiliary verbs will be referred to as the -AUX group. At first sight, a group split based on only one auxiliary production might seem too strict. Previous studies have shown, however, that the acquisition of auxiliaries by Moroccan and Turkish learners of Dutch is a sudden development (Jordens, 2004). Within a short period of time, there is a steep increase in the use of auxiliary verbs, and they are used with different lexical verbs from their first emergence. Based on this evidence, it was chosen to use the rather strict criterion of only one auxiliary production for learners to be included in the +AUX group. The utterance Ik heb vergeten "I have forgotten," was not taken into account, however, as this utterance is likely to be used as an (unanalyzed) formula.

Table 1 shows the mean number of auxiliaries, standard deviations, and ranges for the Moroccan +AUX group, the Turkish +AUX group, and the Dutch native speakers. Because only 10 native speakers completed all three production tasks, the native speaker group is relatively small in comparison to the L2 groups. 
Table 1. Auxiliary use in the production data of the Moroccan $+A U X$ group, Turkish $+A U X$ group, and Dutch controls

\begin{tabular}{lrrr}
\hline \hline & Mean & \multicolumn{1}{c}{$S D$} & Range \\
\hline Moroccan +AUX $(n=31)$ & 14.6 & 12.5 & $1-47$ \\
Turkish +AUX $(n=25)$ & 5.9 & 7.5 & $1-27$ \\
Dutch controls $(n=10)$ & 7.5 & 1.4 & $5-10$ \\
\hline \hline
\end{tabular}

Table 2. Verb placement in the production data of the $+A U X$ group

\begin{tabular}{|c|c|c|c|c|}
\hline & \multicolumn{2}{|c|}{$\begin{array}{l}\text { Moroccan Learners } \\
\qquad(n=31)\end{array}$} & \multicolumn{2}{|c|}{$\begin{array}{l}\text { Turkish Learners } \\
\quad(n=25)\end{array}$} \\
\hline & $\mathrm{V}-\mathrm{NEG}$ & $* \mathrm{NEG}-\mathrm{V}$ & $\mathrm{V}-\mathrm{NEG}$ & $* \mathrm{NEG}-\mathrm{V}$ \\
\hline Lexical verbs & $78 \%$ (138) & $22 \%(38)$ & $37 \%(71)$ & $63 \%(121)$ \\
\hline Auxiliaries & $100 \%(25)$ & $0 \%(0)$ & $100 \%(22)$ & $0 \%(0)$ \\
\hline
\end{tabular}

The table shows a wide range in auxiliary use: some speakers (five in the Moroccan group and three in the Turkish group) produce only 1 auxiliary, whereas other use more than 40 . On average, the Moroccans produce more auxiliaries than the Turkish learners and even more than the Dutch natives. The difference between the two language groups might be due to L1 influence, given that Moroccan Arabic, but not Turkish, has auxiliary verbs. The higher occurrence of auxiliaries in the learner group when compared to the Dutch controls is clearly due to a general difference in length of retellings: the learners' retellings were generally more detailed and less elliptical than the natives' retellings, and hence, there were more occasions to use auxiliary verbs in the former group.

\section{Verb placement in production in the $-A U X$ and $+A U X$ groups}

All sentences containing a negator and a lexical or auxiliary verb in the learners' productions were analyzed for whether the verb preceded or followed the negator. Table 2 and Table 3 provide the absolute and relative frequencies of the placement of lexical verbs and auxiliaries for the +AUX and -AUX groups. In these tables, "V" refers to both lexical verbs and auxiliaries. Thus, in the second row of the tables, V-NEG indicates that the auxiliary preceded the negator, whereas NEG $\mathrm{V}$ indicates that it followed the negator, which was never the case, however.

In the +AUX group, auxiliaries consistently precede negation, whereas lexical verbs are found on both sides of negation. For the Moroccan learners, verb raising is the dominant pattern (78\%), whereas for the Turkish learners, nonraised verbs are more frequent than raised verbs (37\% raised verbs only). This difference between the two language groups is significant by Pearson chi-square value, $\chi^{2}$ $(1)=64.231, p<.001$. In the - AUX group, verb raising is almost negligible: over $90 \%$ of all verbs appeared in a nonraised position. Again, the predominant 
Table 3. Verb placement in the production data of the -AUX group

\begin{tabular}{|c|c|c|c|c|}
\hline & \multicolumn{2}{|c|}{$\begin{array}{l}\text { Moroccan Learners } \\
\quad(n=24)\end{array}$} & \multicolumn{2}{|c|}{$\begin{array}{l}\text { Turkish Learners } \\
\quad(n=21)\end{array}$} \\
\hline & $\mathrm{V}-\mathrm{NEG}$ & $* N E G-V$ & $\mathrm{~V}-\mathrm{NEG}$ & $* \mathrm{NEG}-\mathrm{V}$ \\
\hline Lexical verbs & $9 \%(8)$ & $91 \%(85)$ & $3 \%(6)$ & $97 \%(170)$ \\
\hline Auxiliaries & - & - & - & - \\
\hline
\end{tabular}

use of nonraised verbs is clearer for the Turks (97\%) than the Moroccans $(91 \%)$ in this group, but this difference is not significant, $\chi^{2}(1)=3.326, p>1$. $^{18}$

Taken together, these results provide a positive answer to research question 1: The learners in the +AUX group produce raised verbs (in addition to nonraised ones), but the -AUX group almost exclusively produces verbs in a nonraised position. The differences between the - AUX and +AUX learners are significant for both language groups: $\chi^{2}(1)=119.478, p<.001$ for the Moroccans; $\chi^{2}(1)=$ $62.544, p<.001$ for the Turks.

The question arises whether the relation between auxiliaries and verb raising is a causal one, as claimed in previous studies, or whether the two develop in parallel. The data show that verb raising is rather widespread in the +AUX group: 29 out of the 31 Moroccan learners use verb raising and 23 out of the 25 Turkish learners do. The remaining four learners could be classified as "Stage 2" learners in terms of Becker's (2005) model: they produce auxiliaries but no verb raising, suggesting that auxiliary acquisition precedes the acquisition of verb raising rather than vice versa. This is important, as the reverse pattern would be hard to reconcile with the idea that auxiliaries lead to verb raising. The data also show that some learners in the -AUX group can produce verb raising, an unexpected finding if one assumes that auxiliaries drive verb raising. A closer look suggests, however, that these cases may not reflect productive use of verb raising. Out of all the 14 examples, six are self-corrections of the type in (11), that were uttered hesitantly, and seem to reflect the application of a meta-linguistic rule rather than productive grammatical knowledge: in (11), a \# symbol indicates a 2-s pause. Four utterances are cases of constituent negation of the type in (12) where negation has narrow scope over boven "up."

(11) Niet pakken telefoon \#\# pak niet

Not take-inf phone \#\# take-fin not

"He doesn't pick up the phone"

(12) Maar hij kijkt niet boven, alleen achter

But he look-fin not up, only behind

"But he doesn't look up, he only looks behind"

If we leave aside these cases, it appears that only one learner in the -AUX group produces verb raising in a targetlike manner. This finding together with most but not all learners in the +AUX group use verb raising tentatively suggests that auxiliaries cause verb raising. In line with earlier claims in the literature, auxiliaries would provide a landing site for lexical verbs to be raised to (Vainikka 
\& Young-Scholten, 1996a, 1996b) or lead to the acquisition of finiteness marking, and concomitantly verb raising, because they spell out finites marking to the learner (Becker, 2005). However, this evidence is not very robust. It remains for further research to check whether auxiliaries drive verb raising or whether the two phenomena only develop in parallel. Thus, the clear finding is that there is a clear difference between auxiliary users and "nonauxiliary users" in L2 Dutch such that the former almost always produce verb raising, but the latter do not, or only very rarely so. In the next sections, the results of the elicited imitation and sentence-matching experiments will be discussed to see whether the same patterns are found when other types of data are considered.

\section{RESULTS FOR ELICITED IMITATION}

\section{Coding and scoring}

The results from the elicited imitation task showed that learners frequently changed the original stimuli in their responses. Syntactic, morphological, and semantic changes were found, suggesting that the learners did actively reconstruct the stimuli rather than repeat them verbatim, at least in the overwhelming majority of cases. The responses in (13) and (14) illustrate a semantic and morphosyntactic change, respectively:

(13) Stimulus: *De burgemeester niet werkt op een groot kantoor

"The mayor not works in a big office"

Response: *Die burgemeester niet werk op de postkantoor

"The mayor not work in the post office"

(14) Stimulus: De mannen hebben niet naar de muziek geluisterd

"The men have not to the music listened"

Response: Die mannen hebben niet luisteren muziek

"The men have not listen music"

For all responses, whether the verb preceded or followed negation was determined. When learners repeated a sentence more than once or produced a self-correction, only their last response was considered. Responses in which a lexical verb had been changed to another lexical verb (e.g., praten > luisteren "talk > listen") were retained for analysis.

\section{Results}

Table 4 and Table 5 show the data for the Moroccan and Turkish +AUX groups. The numbers in bold indicate the changes that learners made in their responses concerning the position of the verb relative to negation for a given sentence type. Thus, $13.2 \%$ in the second column of Table 4 indicates that 12 out of all 91 responses to stimulus sentences with a lexical verb following negation (*NEG - LEX) were changed into sentences with a lexical verb preceding negation (LEX - NEG). The tables also show how many utterances could be analyzed ("total analyzed") and how often learners left out the verb or the negator in their responses $(2 / 1$ in the last column indicates that out of all responses in a given 
Table 4. Results from elicited imitation for the Moroccan $+A U X$ group $(n=31)$

\begin{tabular}{crccc}
\hline \hline \multicolumn{5}{c}{ Responses } \\
\hline \multicolumn{1}{c}{ Stimuli } & V - NEG & *NEG - V & Total Analyzed & No V/NEG \\
\hline LEX - NEG & $100 \%(93)$ & $\mathbf{0 \%}(0)$ & 93 & $0 / 0$ \\
*NEG - LEX & $\mathbf{1 3 . 2 \%}(12)$ & $86.8 \%(79)$ & 91 & $2 / 1$ \\
AUX - NEG & $100 \%(92)$ & $\mathbf{0 \%}(0)$ & 92 & $1 / 0$ \\
*NEG - AUX & $\mathbf{3 2 . 9 \% ( 2 8 )}$ & $67.1 \%(57)$ & 85 & $7 / 1$ \\
\hline \hline
\end{tabular}

Note: The numbers in bold indicate the changes that learners made in their responses concerning the position of the verb relative to negation for a given sentence type.

Table 5. Results from elicited imitation for the Turkish $+A U X$ group $(n=25)$

\begin{tabular}{ccccc}
\hline \hline \multicolumn{5}{c}{ Responses } \\
\hline \multicolumn{1}{c}{ Stimuli } & V - NEG & *NEG - V & Total Analyzed & No V/NEG \\
\hline LEX - NEG & $89 \%(65)$ & $\mathbf{1 1 \%}(8)$ & 73 & $0 / 2$ \\
*NEG - LEX & $\mathbf{7 . 2 \%}(5)$ & $92.8 \%(64)$ & 69 & $2 / 4$ \\
AUX - NEG & $100 \%(50)$ & $\mathbf{0 \%}(0)$ & 50 & $22 / 2$ \\
*NEG - AUX & $\mathbf{5 9 . 3 \% ( 3 2 )}$ & $40.7 \%(22)$ & 54 & $18 / 0$ \\
\hline \hline
\end{tabular}

Note: The numbers in bold indicate the changes that learners made in their responses concerning the position of the verb relative to negation for a given sentence type.

condition, two responses lacked a verb — a lexical verb or auxiliary depending on the condition — and one had a missing negation). ${ }^{19}$

Table 4 shows that the Moroccan learners changed lexical verbs from a position following negation to a position preceding negation in their responses, but not vice versa ( $13.2 \%$ vs. $0 \%)$. The same holds for auxiliaries, where an even stronger preference for auxiliaries to precede negation was found: $32.9 \%$ of all auxiliary sentences in which the auxiliary followed negation were changed into a grammatical sentence, but the opposite type of change was never made. The following responses illustrate both types of change made by the Moroccan +AUX group: a change from *NEG - LEX into LEX - NEG and from *NEG - AUX into AUX NEG, respectively.

(15) Stimulus: *De jongens en meisjes niet lopen op het strand

"The boys and girls not walk on the beach"

Response: Die jongens en meisjes loopten niet in het strand

"The boys and girls walk not on the beach"

(16) Stimulus: *De meisjes niet hebben op het strand gelopen

"The girls not have on the beach walked"

Response: De meisjes hebben niet op het strand gelopen

"The girls have not on the beach walked" 
Verhagen: Verb placement in second language acquisition

Comparing these findings to the data from the Turkish learners in Table 5, a clear difference can be observed: whereas the Moroccan learners shifted verbs from a position following negation to a position preceding negation, but never vice versa, the Turkish learners also switched lexical verbs to a position following negation. This is exemplified in (17) and (18):

(17) Stimulus: De mannen luisteren niet naar de mooie muziek

"The men listen not to the nice music"

Response: *Die mannen niet luisteren in de muziek

"The men not listen in the music"

(18) Stimulus: De burgemeester werkt niet op een groot kantoor

"The mayor works not in a big office"

Response: De burgemeester niet werk op een kantoor

"The mayor not work in an office"

They produced this type of response more often than the opposite type, in which they shifted a verb from a nonraised to a raised position (11\% vs. $7.2 \%)$. Just like the Moroccan learners, however, the Turkish learners showed a clear preference for auxiliaries to precede negation: no less than 59.3\% of all sentences were changed from *NEG - AUX into AUX - NEG order in this language group, but the opposite type of change did not occur. Consider (19) for an example:

(19) Stimulus:

Response:
*De koningin niet heeft naar de mensen gelachen

"The queen not has to the people laughed"

De koning heeft niet naar de mensen gelacht

"The queen has not to the people laughed"

For both language groups, the differences between the lexical verb and auxiliary condition are significant, $\chi^{2}(1)=9.766, p=.002$, for the Moroccans; $\chi^{2}(1)=$ $38.965, p=.001$, for the Turks, showing that both groups switched auxiliaries more often into a correct position in their responses than lexical verbs. Note, however, that the number of analyzable responses in the auxiliary condition is much lower than in the case of lexical verbs, in particular, in the data from the Turkish learners. A look at the last column shows that this is due to the large number of responses in which the auxiliary was not repeated. The Turkish learners left out the auxiliary in 22 and 18 of all responses to *AUX - NEG and NEG - AUX items, respectively, which constituted $22 \%$ and $30 \%$ of all responses. We will come back to this finding below and discuss it further in the discussion section.

Table 6 and Table 7 present the data for the Moroccan and Turkish -AUX groups. As in Tables 4 and 5, the values in bold indicate the changes that learners made in their responses concerning the position of the verb relative to negation. With one exception, the learners in the -AUX groups did not change nonraised lexical verbs into raised lexical verbs, so they behaved differently from both +AUX groups. Instead, they frequently switched lexical verbs from a raised into a nonraised position: $11.8 \%$ in the data from the Moroccans and $32.2 \%$ in the data from the Turks. This difference is significant, $\chi^{2}(1)=11.655, p=.001$, showing that the Turkish learners changed raised into nonraised lexical verbs significantly more often than the Moroccan learners. 
Table 6. Results from elicited imitation for the Moroccan $-A U X$ group $(n=24)$

\begin{tabular}{ccccc}
\hline \hline \multicolumn{5}{c}{ Responses } \\
\hline \multicolumn{1}{c}{ Stimuli } & V - NEG & *NEG - V & Total Analyzed & No V/NEG \\
\hline LEX - NEG & $88.2 \%(60)$ & $\mathbf{1 1 . 8 \%}(8)$ & 68 & $0 / 4$ \\
*NEG - LEX & $\mathbf{1 . 4 \% ( 1 )}$ & $98.6 \%(69)$ & 70 & $0 / 2$ \\
AUX - NEG & $100 \%(66)$ & $\mathbf{0 \%}(0)$ & 66 & $4 / 2$ \\
*NEG - AUX & $\mathbf{4 3 . 8 \% ( 2 8 )}$ & $56.2 \%(36)$ & 64 & $8 / 0$ \\
\hline \hline
\end{tabular}

Note: The numbers in bold indicate the changes that learners made in their responses concerning the position of the verb relative to negation for a given sentence type.

Table 7. Results from elicited imitation for the Turkish -AUX group $(n=21)$

\begin{tabular}{|c|c|c|c|c|}
\hline \multicolumn{5}{|c|}{ Responses } \\
\hline Stimuli & $\mathrm{V}-\mathrm{NEG}$ & $* \mathrm{NEG}-\mathrm{V}$ & Total Analyzed & No V/NEG \\
\hline LEX - NEG & $67.8 \%(40)$ & $32.2 \%$ (19) & 59 & $1 / 2$ \\
\hline$*$ NEG - LEX & $100 \%(0)$ & $0 \%(54)$ & 54 & $0 / 9$ \\
\hline AUX - NEG & $95.2 \%(20)$ & $4.8 \%(1)$ & 21 & $40 / 0$ \\
\hline$* N E G-A U X$ & $44.7 \%(17)$ & $55.3 \%(21)$ & 38 & $22 / 0$ \\
\hline
\end{tabular}

Note: The numbers in bold indicate the changes that learners made in their responses concerning the position of the verb relative to negation for a given sentence type.

It is striking that Tables 6 and 7 also show that the -AUX group often changed auxiliaries from a position following negation to a position preceding negation. These changes are remarkable given that the learners in the -AUX group could not produce auxiliaries. The number of "corrected" auxiliary sentences produced by the Moroccan -AUX group outnumbers those made by the Moroccan +AUX group: $43.8 \%$ versus $32.9 \%$. The Turkish -AUX group also frequently shifted the auxiliary from a position following to a position preceding negation (44.7\%), but they did not do so more frequently than the Turkish + AUX group (59.3\%).

Just as was observed for the +AUX group, the learners in the -AUX group often left out the auxiliary verb in their responses: $65.5 \%$ of the responses to AUX NEG stimuli in the Turkish - AUX group did not contain an auxiliary and the same held for $36.7 \%$ of all responses to ${ }^{*} \mathrm{NEG}-\mathrm{AUX}$ stimuli. ${ }^{20}$ For an illustration, consider (20) and (21):

(20) Stimulus: De mannen hebben niet naar de muziek geluisterd

"The men have not to the music listened"

Response: De mannen $\underline{0}$ niet muziek luisteren

"The men not music listen"

(21) Stimulus: De meisjes hebben niet op het strand gelopen

"The girls have not on the beach walked"

Response: De meisjes $\underline{0}$ niet op het strand lopen

"The girls not on the beach walk" 
Verhagen: Verb placement in second language acquisition

Table 8. Auxiliary drop in the filler sentences from the elicited imitation task

\begin{tabular}{crrrrr}
\hline \hline \multirow{2}{*}{ Stimuli } & \multicolumn{2}{c}{ Moroccan Learners } & & \multicolumn{2}{c}{ Turkish Learners } \\
\cline { 2 - 3 } \cline { 5 - 6 } & +AUX Group & -AUX Group & & +AUX Group & -AUX Group \\
\hline Fillers (+inv.) & $0 \%(0 / 93)$ & $15.3 \%(11 / 72)$ & & $36 \%(27 / 75)$ & $47.6 \%(30 / 63)$ \\
Fillers (-inv.) & $2.3 \%(7 / 93)$ & $23.6 \%(17 / 72)$ & & $40 \%(30 / 75)$ & $50.8 \%(32 / 63)$ \\
\hline \hline
\end{tabular}

An interesting question is why learners left out hebben so frequently. To find out whether the phenomenon was somehow related to the presence of negation, the filler items containing auxiliaries were analyzed to see whether the learners showed the same behavior for these items. Recall from above that (some of) the filler items involved inversion/no-inversion sentences of the following type: Elke dag heeft de meneer een sigaret gerookt versus *Elke dag de meneer heeft een sigaret gerookt ("Every day has the man/*the man has a cigarette smoked"). Table 8 shows for all four learner groups how often they "dropped" hebben in their responses to these items out of the total number of (analyzable) responses.

Again, the tendency is particularly strong in the Turkish group: the Turkish -AUX group left out hebben in about half of the cases and even the learners of the Turkish +AUX group often "dropped" the auxiliary (36\% and 40\%, respectively). The Moroccan -AUX group also left out hebben relatively often, but much less often so than the Turkish -AUX group, $\chi^{2}(1)=26.786, p<.001$, when both filler types are collapsed. For the Moroccan +AUX group, "auxiliary drop" is close to absent, so the learners in this group performed very differently from the Turkish + AUX group. In the discussion, we will come back to these findings and propose an explanation of why learners "dropped" the auxiliary as well as why the Turkish learners did so more often than the Moroccan learners.

\section{Summary}

The elicited imitation data show some clear parallels to the production data. First, the +AUX group changed lexical verbs from a nonraised to a raised position, whereas the -AUX group changed lexical verbs from a raised to a nonraised position. Second, the +AUX group never shifted auxiliaries to the right of negation in their responses. Third, a difference between the two language groups was found: the Turkish learners had a stronger preference for nonraised verbs overall, because in the +AUX and - AUX group the changes from raised into nonraised verbs were more frequent than in the data from the Moroccan learners. The elicited imitation results also differed from the production data, however. First, the Moroccan +AUX group never switched raised lexical verbs into nonraised ones even though their production data did contain verbs in nonraised position. Second, and of the most interest, the - AUX group frequently switched auxiliary verbs to a correct position, even though they did not use such verbs in production. This finding suggests that learners who do not yet produce auxiliary verbs can be sensitive to the placement of such verbs relative to negation. The findings for production and elicited imitation 
Verhagen: Verb placement in second language acquisition

Table 9. Result summary for production and elicited imitation

\begin{tabular}{|c|c|c|c|}
\hline Group & Verb & Production & Elicited Imitation \\
\hline$+\mathrm{AUX}$ & LEX & LEX - NEG + NEG - LEX & $\begin{array}{l}\text { Moroccans: LEX - NEG } \\
\text { Turks: LEX - NEG + NEG - LEX }\end{array}$ \\
\hline & AUX & AUX - NEG & AUX - NEG \\
\hline -AUX & $\begin{array}{l}\text { LEX } \\
\text { AUX }\end{array}$ & NEG - LEX & $\begin{array}{l}\text { NEG - LEX } \\
\text { AUX - NEG }\end{array}$ \\
\hline
\end{tabular}

are summarized in Table 9. This table shows for both groups and for each verb type separately which structures learners produced in the production tasks (first column) and preferred in elicited imitation (second column).

\section{RESULTS FOR SENTENCE MATCHING}

Before presenting the results, the next section addresses the analyses that were performed on the data from the sentence matching task.

\section{Analyses of the sentence matching data}

As is standard in sentence-matching experiments, only reaction times to matching pairs were considered for analysis. All responses to nonmatching pairs as well as incorrect responses to matching pairs were removed. Furthermore, all responses for which yes/no questions were wrongly answered were excluded. In determining the overall error rate for each participant, however, responses to nonmatching pairs were taken into account, because it was assumed that such responses provide an indication of participants' overall task performance. In the control group, two participants with an error rate greater than $15 \%$ were excluded from the analysis (see also Duffield et al., 2002). For the learner group, no such criterion was applied, because it was assumed that learners' errors, unlike native speakers' errors, could be due to problems with vocabulary or phonetic decoding instead of merely "bad processing."

Means and standard deviations were calculated for the scores of each participant on each of the four conditions separately. The reaction times that fell beyond the cutoff value of $2 S D$ above or below a participant's individual mean for a given condition were excluded. As a result of error deletion and cleaning, $2.5 \%$ of all responses of the control group and $8.5 \%$ of all responses of the learner group were removed.

The remaining reaction times were analyzed with the general linear model repeated-measures procedure in SPSS for the native speakers and learners separately. In the analysis of the native speakers, there were two within-subject factors: Verb Placement, with two levels (raised vs. nonraised) and Verb Type, with two levels (lexical verb vs. auxiliary). In the analysis of the learner data, there were the same two within-subject factors as well as two between-subject factors: Language, with two levels (Moroccan Arabic and Turkish) and Learner Group, with two levels 
Table 10. Results from sentence matching for the native speakers $(n=26)$

\begin{tabular}{lcr}
\hline \hline & \multicolumn{2}{c}{$\begin{array}{c}\text { Response } \\
\text { Time (ms) }\end{array}$} \\
\cline { 2 - 3 } & Mean & SD \\
\hline 1. LEX - NEG & 341 & 115 \\
2. *NEG - LEX & 397 & 137 \\
3. AUX - NEG & 336 & 123 \\
4. *NEG - AUX & 390 & 163 \\
\hline \hline
\end{tabular}

(+AUX and - AUX group). In line with earlier sentence-matching studies, both $F 1$ and $F 2$ were calculated, which means that separate analyses were performed over subjects and items.

\section{Results for the native speakers}

The mean response latencies and standard deviations for the control group are presented in Table 10. A repeated-measures analysis of variance showed that there was a main effect of verb placement, both by subject, $F 1(1,25)=10.297, p=$ .004 , and by item, $F 2(1,23)=4.508, p=.045$. This effect indicates that responses were faster to sentences with raised than to sentences with nonraised verbs.

No interaction with verb type was found, indicating that speakers responded faster to sentences with raised verbs independently of whether these sentences contained a lexical verb or an auxiliary. These results show that the sentencematching task taps into the processing of grammaticality in the case of verb raising, at least when data from native speakers are considered.

\section{Results for the + AUX group}

No effects were found for the learners in the +AUX group. The factor Verb Placement did not yield a significant result, $F 1(1,55)=1.285, p>.1$ and $F 2$ $(1,23)=0.005, p>.1$, and neither did the factor Verb Type, $F 1(1,55)=1.179$, $p>.1$ and $F 2(1,23)=0.006, p>.1$. The interaction between Verb Placement and Verb Type was also not significant, $F 1(1,55)=0.983, p>.1$. Table 11 presents the mean reaction times and standard deviations for this group.

The data show that responses were equally fast to raised and nonraised verbs (lexical verbs) or even slightly faster to nonraised verbs (auxiliaries). A low power value $(0.2)$ suggests, however, that there was high within-group variation in the + AUX group. Therefore, a series of post hoc (covariate) analyses was performed to test whether general response speed, number of postverbal negations in production, and number of auxiliaries in production influenced the results. Only "auxiliary use" turned out to significantly influence the results of the Moroccan learners. More precisely, an interaction effect between verb placement and auxiliary use, $F 1$ (1, $30)=4.659, p=.039$, showed that the Moroccan learners who used less than 
Table 11. Results from sentence matching for the $+A U X$ group $(n=56)$

\begin{tabular}{lcr}
\hline \hline & \multicolumn{2}{c}{$\begin{array}{c}\text { Response } \\
\text { Time (ms) }\end{array}$} \\
\cline { 2 - 3 } & Mean & SD \\
\hline 1. LEX - NEG & 502 & 228 \\
2. *NEG - LEX & 501 & 223 \\
3. AUX - NEG & 554 & 301 \\
4. *NEG - AUX & 489 & 239 \\
\hline \hline
\end{tabular}

Table 12. Results from sentence matching for the $-A U X$ group $(n=45)$

\begin{tabular}{lcr}
\hline \hline & \multicolumn{2}{c}{$\begin{array}{c}\text { Response } \\
\text { Time (ms) }\end{array}$} \\
\cline { 2 - 3 } & Mean & SD \\
\hline 1. LEX - NEG & 525 & 228 \\
2. *NEG - LEX & 423 & 193 \\
3. AUX - NEG & 502 & 212 \\
4. *NEG - AUX & 683 & 407 \\
\hline \hline
\end{tabular}

15 auxiliaries in the production tasks responded faster to nonraised lexical verbs, whereas the Moroccan learners who produced more than 15 auxiliaries responded faster to raised lexical verbs. For the auxiliary sentences, no effects were found.

In sum, the results of the +AUX group did not show effects, with the exception of a preference for raised or nonraised verbs lexical verbs in the Moroccan group, depending on how frequently learners used hebben in production.

\section{Results for the - AUX group}

For the -AUX group, whose data are presented in Table 12, a main effect of verb placement was found, both by subject and by item, $F 1(1,44)=8.544, p=.005$, and $F 2(1,23)=12.822, p=.002$. There was also an interaction effect between verb placement and verb type, $F 1(1,44)=18.597, p<.001$, and $F 2(1,23)=$ $11.359, p=.003$. These effects show that learners responded significantly faster to nonraised verbs in the case of lexical verbs and raised verbs in the case of auxiliaries. A post hoc paired $t$ test showed that these differences were significant for the lexical verb sentences, $t(44)=3.235, p=.002$, and auxiliary sentences, $t(44)=3.437, p=.001$. 
Verhagen: Verb placement in second language acquisition

Table 13. Overall result summary

\begin{tabular}{lccll}
\hline \hline Group & Verb & Production & \multicolumn{1}{c}{ Elicited Imitation } & Sentence Matching \\
\hline +AUX & LEX & $\begin{array}{r}\text { LEX - NEG }+ \\
\text { NEG - LEX }\end{array}$ & $\begin{array}{c}\text { Moroccans: LEX - NEG } \\
\text { Turks: LEX - NEG } \\
\text { + NEG - LEX }\end{array}$ & No preferences \\
& & & AUX - NEG & No preferences \\
& AUX & AUX - NEG & NEG - LEX & NEG - LEX \\
AUX & LEX & NEG - LEX & AUX - NEG & AUX - NEG \\
& AUX & - & AUX \\
\hline \hline
\end{tabular}

The finding that nonraised lexical verbs were processed faster than raised lexical verbs is in line with learners' production. Learners' faster processing of raised auxiliaries than nonraised auxiliaries is clearly ahead of production, given that the - AUX group did not produce auxiliary verbs. Both results are comparable to those from the elicited imitation task, where the -AUX group changed lexical verbs from raised to nonraised, but showed the opposite type of response in sentences with auxiliaries.

\section{Summary}

Like the results from elicited imitation, the sentence matching results showed that the -AUX group preferred auxiliaries in a position preceding negation, but lexical verbs in a position following negation. For the +AUX group, no clear effects were found except that Moroccan learners who produced more than 15 auxiliaries preferred raised over nonraised lexical verbs, whereas learners who produced fewer auxiliaries preferred nonraised over raised lexical verbs. The results for production, elicited imitation, and sentence matching are summarized in Table 13.

\section{DISCUSSION}

The results of this study corroborate earlier findings for the acquisition of verb raising in production (Becker, 2005; Dimroth, 2008; Vainikka \& Young-Scholten, 1996a, 1996b) and add to these findings a number of observations from elicited imitation and sentence matching. Most important, these findings show that learners can be sensitive to the grammaticality of structures before they are able to produce such structures in their own speech. In the current study, this early sensitivity to grammaticality reflects which structures learners will produce when they become more proficient in the $\mathrm{L} 2$.

How can we explain the finding that the learners preferred auxiliary verbs in a correct position before they produced such verbs? A possible answer is that the same principle is at work as in production, namely, semantic scope marking. According to this idea, sentences in which the negator precedes its domain of application are processed faster than sentences in which the negator is placed within this domain (LEX - NEG) or takes extra elements in its scope (NEG - AUX). Alternatively however, the results might be accounted for in terms 
of input frequency. Although the negator follows finite verbs in Dutch main clauses, both the complex "negator-lexical verb" and the complex "negator-auxiliary" occur in the input. The former sequence occurs in imperatives (Niet kijken! "Not watch!"), sentences with modal verbs (Ik wil niet werken "I want not work"), and subordinate clauses (Ik denk dat zij niet werken "I think that they not work"). However, the sequence negator-auxiliary is only found in subordinate clauses (Ik denk dat zij niet hebben gewerkt "I think that they not have worked"). That the negator-auxiliary occurs less frequently than the negator-lexical verb could thus explain why learners at a certain stage of acquisition prefer lexical verbs to follow negation, but auxiliaries to precede negation. It seems unlikely, however, that the results are due to input frequency alone: the preference for auxiliaries in a correct position with respect to negation in the -AUX group was remarkably strong and it does not seem very plausible that relatively small differences in input frequency caused this preference.

One finding that deserves further discussion is the null result for the +AUX group in the sentence-matching task. The absence of an effect for lexical verb sentences is not surprising, because the +AUX group produced both raised and nonraised lexical verbs in negated sentences. It is less clear, however, why the + AUX group did not prefer auxiliaries in a correct position. A question is why these learners did not show a processing preference for the type of structure they consistently produced in their own speech and never changed into an incorrect alternative in elicited imitation.

As discussed above, Beck (1998) also found that the least advanced learners in her study showed a processing preference for raising over nonraising that was not found for more advanced learners. Similarly, Eubank and Grace (1996) found that learners of English did not respond differently to raising and nonraising even though they were highly advanced in the L2. In both studies, optionality was proposed as an explanation: verb raising is optional for these learners and therefore no processing preferences are found. Although optionality might explain the present null result for lexical verbs, it is less clear how it could account for the lack of an effect for auxiliary sentences. Rather, the results might be due to a task artifact: the presentation of negated auxiliary sentences with incorrect auxiliary placement might have led to what could be called "task-induced optionality." In other words, on the basis of the ungrammatical sentences that were presented to them, learners might have created ad hoc representations in which auxiliaries follow negation, in addition to their already existing representations in which auxiliaries precede negation. To test this idea, the responses of the +AUX group in the first half of the task were compared to those in the second half. The results were not significant, $F 1(1,55)=0.000, p=.992$, which suggests that responses did not change as a function of learners' exposure to the stimuli items.

Another possible explanation of the null result for the +AUX group could be a problem with the sentence-matching task. Several studies using the sentencematching paradigm have found null results in nonnative speakers (Beck, 1998; Eubank \& Grace, 1996; Gass, 2001) as well as for certain syntactic violations in native speakers (Freedman \& Forster, 1985). This casts doubt on the appropriateness of the task. Gass (2001) conducted a visual sentence-matching task with 
native speakers and learners of French to investigate what people actually are doing when they perform a sentence-matching task. She found that reading times for the second sentence were about $1000 \mathrm{~ms}$ shorter than for the first sentence and she concluded that "most likely, learners were attempting to do a word-by-word match rather than reading and processing" (p. 439). She proposed that sentencematching tasks may be valid with a certain level of proficiency only. Even though word-by-word matching seems less likely when the task is performed auditorily, it cannot be excluded that participants process sentences in a sentence-matching task differently from processing language in more natural situations.

An alternative way to account for the null result, then, is to assume that learners processed the sentences in a special manner. In studies on sentence processing, it has been argued that instead of creating fully specified syntactic representations of sentences, language users may create less detailed representations that are mainly based on lexical-semantic information. For native speakers, such "shallow processing" has been found for ambiguous sentences (Ferreira, Christianson, \& Hollingworth, 2001; Ferreira \& Patson, 2007) as well as certain types of ungrammaticality (Tabor, Galantucci, \& Richardson, 2004). For L2 processing, it has been argued that "shallow processing" is even more plausible: learners" grammars are incomplete or different from the target language, so learners mainly rely on semantic information (Clahsen \& Felser, 2006). If the +AUX group merely processed sentences for meaning, this could explain why they did not respond differently to grammatical and ungrammatical sentences: both had the same meaning and the only difference between the two conditions concerned the ordering of the elements. An important question that remains, then, is the following: Why did the -AUX group show clear effects instead of shallow processing? A speculative answer would be that optionality and shallow processing go together in L2 processing. That is, learners who have alternative representations of one linguistic phenomenon (i.e., optionality) might be more susceptible to the relaxation of formal constraints than learners who do not have optional syntactic structures. Under this idea, the optional raising of lexical verbs in the +AUX group may have led to optionality with auxiliary verbs. Thus, because learners' grammars allow for the coexistence of different syntactic structures with the same meaning, it might have enhanced learners' relaxation of syntactic constraints, resulting in a greater reliance on semantic information. No firm conclusions can be drawn on the basis of the current data, however, and the idea that optionality might promote shallow processing needs further investigation.

Learners' frequent omission of auxiliary verbs in elicited imitation may also be due to "shallow processing." This idea is immediately plausible: auxiliaries lack a clear lexical meaning and therefore constitute good candidates for omission when sentences are mainly processed for semantic information. Other elements that were often left out by learners were also poor in meaning: articles, agreement morphemes, connectives such as "and," and prepositions. In addition, the position of hebben in a sentence might have facilitated its omission. Previous research has shown that L2 learners find it easier to imitate structures at the beginning of sentences than those at the end, which in turn are easier than those in the middle (Naiman, 1974). Clearly, auxiliaries might then also be difficult to process (and imitate) because of their sentence medial position. 
The finding that the Turkish learners dropped hebben more frequently than the Moroccan learners is likely to be due to L1 influence. First, unlike Dutch and Moroccan Arabic, Turkish lacks auxiliary verbs, which probably makes it harder for Turkish learners to perceive hebben in the input and/or figure out its function. Second, Moroccan Arabic and Turkish differ in their basic word order in that finite verbs occur in initial or second position in Moroccan Arabic, but sentence-finally in Turkish. Earlier research has demonstrated that this difference shapes word order preferences of Moroccan and Turkish learners of Dutch in production: Moroccan learners typically place verbs in sentence medial position, whereas Turkish learners typically put them in final position (Jagtman, 1994; Jansen, Lalleman \& Muysken, 1981). These patterns have been argued to result from L1-based processing differences: although Moroccan learners focus their attention on the middle part of a sentence, where they expect to find a verb, Turkish learners of Dutch look for the verb in final position. The finding that the Turks left out hebben far more often than the Moroccan learners (and sometimes even left out lexical verbs in the lexical verb sentences) fits well with this idea. Of interest, this tendency was extremely persistent: even those Turkish learners who used over 20 auxiliaries in the production tasks abundantly left out hebben in elicited imitation.

Independent evidence for the idea of L1-based processing differences between Moroccan and Turkish learners of Dutch comes from the offline (accuracy) data collected in the sentence-matching task, where some nonmatching fillers involved a lexical difference between the two sentences of a pair. Crucially, these changes could occur in first position (nonmatching subjects), middle position (nonmatching verbs), or final position (nonmatching objects). An analysis of learners' accuracy scores showed that the Turks correctly judged 59\% of all nonmatching pairs with a change in the middle as being different, whereas the Moroccan learners correctly judged $73 \%$ of such pairs. No clear differences were found for the other filler pairs. This finding provides further support for the idea that the typological characteristics of the L1 may influence L2 processing.

Thus, how exactly does L1 influence relate to the acquisition of auxiliaries? Clearly, the Moroccan speakers outperformed the Turkish speakers. This seems to be because verb raising is an option in the Moroccan learners' L1 and perhaps because of the above-explained L1-based processing differences that would make Moroccan learners focus on the verbal part of the sentence in the L2 input. Another important finding was that the +AUX group outperformed the -AUX group, regardless of learners' L1. This suggests that Moroccan learners cannot take advantage of their L1 until auxiliaries come into play: it is only after auxiliaries have been added to the system that Moroccan learners of Dutch can transfer their L1 FPs. Such a developmental account is in line neither with the predictions made by the full transfer account (Schwartz \& Sprouse, 1996) according to which the complete L1 syntactic system is transferred to the earliest stages of L2 acquisition nor with the predictions made by the minimal trees hypothesis (Vainikka \& YoungScholten, 1996a, 1996b), according to which FPs can never be transferred.

Taken together, the results of this study corroborate earlier findings on the relation between auxiliaries and verb placement in production from L2 German for Dutch, and demonstrate that these findings also hold for imitation and sentence 
Verhagen: Verb placement in second language acquisition

processing. More specifically, the results show that L2 learners can have grammatical knowledge of auxiliary placement before they are able to use this knowledge in production. These outcomes not only provide evidence for the different behavior of auxiliaries and lexical verbs in early L2 Dutch but also show that combining production and imitation/processing data may lead to a more complete picture of L2 development.

\section{APPENDIX A: ITEMS OF THE ELICITED IMITATION TASK}

To preserve space, only one sentence type is given for each experimental item and only example items of the fillers are provided.

\section{Experimental items}

1. De minister praat niet over het grote probleem ("The minister talks not about the big problem") *De minister niet praat over het grote probleem ("The minister not talks about the big problem") De minister heeft niet over het probleem gepraat ("The minister has not about the problem talked") *De minister niet heeft over het probleem gepraat ("The minister not has about the problem talked")

2. De koningin lacht niet naar de aardige mensen ("The queen laughs not to the nice people")

3. De burgemeester werkt niet op een groot kantoor ("The mayor works not at a big office")

4. De oude leraren dansen niet op het feestje ("The old teachers dance not at the party")

5. De mannen luisteren niet naar de mooie muziek ("The men listen not to the nice music")

6. De jongens en meisjes lopen niet op het strand ("The boys and girls walk not on the beach")

\section{Examples of filler items}

1. De man geeft een mooi cadeau aan de directeur ("The man gives a nice present to the director") *De man geven een mooi cadeau aan de directeur ("The man give a nice present to the director") De man heeft een cadeau aan de directeur gegeven ("The man has given a nice present to the director") *De man hebben een cadeau aan de directeur gegeven ("The man have given a present to the director")

2. Elke dag rookt de oude meneer rookt een sigaret ("Each day smokes the old man a cigarette") *Elke dag de oude meneer rookt een sigaret ("Each day the old man smokes a cigarette") Elke dag heeft de meneer een sigaret gerookt ("Each day has the man a cigarette smoked") *Elke dag de meneer heeft een sigaret gerookt ("Each day the man has a cigarette smoked") 


\section{APPENDIX B: ITEMS OF THE SENTENCE-MATCHING TASK}

Only one sentence of a pair is given for the experimental items, because all pairs were matching. For the filler items, both sentences are presented, but only one example is provided.

\section{Experimental items}

1. Nadia en Bushra dansen niet op het feest ("N. and B. dance not at the party")

*Nadia en Bushra niet dansen op het feest ("N. and B. not dance at the party") Nadia en Bushra hebben niet op het feest gedanst ("N. and B. have not at the party danced") *Nadia en Bushra niet hebben op het feest gedanst ("N. and B. not have at the party danced")

2. Hans en Sara dansen niet in het café ("H. and S. dance not in the "afé")

3. Roos en Hessa eten niet bij hun vriendin ("R. and H. eat not at their friend's")

4. Sam en Peter eten niet in de klas ("S. and P. eat not in the class")

5. Abdul en Nada fietsen niet in de stad ("A. and N. bike not in the city")

6. Yassir en Edwin fietsen niet op het gras ("Y. and E. bike not on the grass")

7. Anna en Frank koken niet in de keuken ("A. and F. cook not in the kitchen")

8. Gul en Nermin koken niet voor het kind ("G. and N. cook not for the child")

9. Dirk en Hans luisteren niet naar de radio ("D. and H. listen not to the radio")

10. Hanif en Thara luisteren niet naar de muziek ("H and T listen not to the music")

11. Jos en Wim praten niet over de vakantie ("J. and W. talk not about the holiday")

12. Femke en Lotte praten niet met de meneer ("F. and L. talk not with the man")

13. Marie en Rashid roken niet in de kamer ("M. and R. smoke not in the room")

14. Kees en Sander roken niet in de trein ("K. and S. smoke not in the train")

15. Habib en Haifa slapen niet op de bank ("H. and H. sleep not on the couch")

16. Marieke en Chris slapen niet in de bus ("M. and C. sleep not in the bus")

17. Daan en Ed studeren niet in Turkije ("D. and E. study not in Turkey")

18. Bert en Freek studeren niet in Marokko ("B. and F. study not in Morocco")

19. Piet en Engin werken niet in een restaurant ("P. and E. work not in a restaurant") 
Verhagen: Verb placement in second language acquisition

20. Elmas en Pinar werken niet in een dorp ("E. and P. work not in a village")

21. Ayse en Ozlem wonen niet in Nederland ("A. and O. live not in The Netherlands")

22. Nasser en Asli wonen niet in Rotterdam ("N . and A. live not in Rotterdam")

23. Mehmet en Anke wachten niet op het meisje ("M. and A. wait not for the girl")

24. Anneke en Suzan wachten niet op de trein ("A. and S. wait not for the train")

\section{Examples of filler items}

1. Grammatical-lexically different: Job en Gert betalen geld aan de mevrouw - Job en Gert betalen geld aan de meneer ("J. and G pay money to the woman") ("J. and G. pay money to the man")

2. Grammatical—syntactically different: Ali maakt een kop thee voor zijn vader ("A. makes a cup of tea for his father")

— Ali maakt voor zijn vader een kop thee ("A. makes for his father a cup of tea")

3. Ungrammatical-lexically different: *Snel de politie Max en Luuk bellen ("Quickly the police M. and L. call")

— *Snel het ziekenhuis Max en Luuk bellen ("Quickly the hospital M. and L. call")

4. Ungrammatical - syntactically different: *Rashida naar het station gaat op de fiets ("R. to the station goes by bike")

— *Rashida naar het station op de fiets gaat ("R. to the station by bike goes")

\section{ACKNOWLEDGMENTS}

This study was carried out at the Max Planck Institute for Psycholinguistics in Nijmegen and the Free University Amsterdam and formed part of the research project "Information structure in language acquisition." I thank Christine Dimroth, Peter Jordens, Sarah Schimke, Wolfgang Klein, Leah Roberts, Melissa Bowerman, and two anonymous reviewers for their helpful comments on earlier versions of this paper.

\section{NOTES}

1. The same is true of L1 acquisition, where auxiliaries appear in a finite form and in raised position from their first appearance (see Jordens, 2002, for Dutch; Verrips \& Weissenborn, 1992, for French; Wexler, 1994, for English/German; and Phillips, 1995, for English).

2. The principle of transparent scope relations has also been used as an explanation of the L2 acquisition of verb placement in sentences with focus particles and adverbs (Dimroth, 2002) and has also been mentioned as an important principle in natural languages in the literature on negation. In a cross-linguistic sense, negation most often precedes the domain it semantically affects, usually the verbal predicate (Dahl, 1979). Horn (1989) even classifies preverbal negation as the "prototype." He refers to this idea as the "Neg first principle": "The Neg first principle expresses the strong 
tendency for negative markers to gravitate leftwards so as to precede the finite verb or other possible foci of negation" (Horn, 1989, p. 452).

3. However, from the viewpoint of information structure, clear differences exist between negation and adverbs. Negation usually bears scope over the focus part of an utterance, whereas adverbs can be situated in the topic part, bearing scope over the entire utterance (e.g., "Tomorrow, I will not go to work").

4. The reason for Beck (1998) to split learners into different groups based on their agreement and inversion scores was to test whether functional categories are present from the initial stages of acquisition or acquired later in acquisition, and thus contribute to the debate on the presence/absence of functional categories at the initial state (Eubank, 1993/1994; Schwartz \& Sprouse, 1996; Vainikka \& Young-Scholten, 1996a, 1996b). More precisely, she hypothesized that if functional categories are present, the agreement group should show a preference for raised verbs, whereas the no-agreement group should show no preference (i.e., they should optionally allow verb raising). Moreover, on the assumption that functional categories are transferred from the L1 (and not related to agreement), those learners who showed evidence of a $\mathrm{CP}$ (i.e., the inversion group) should prefer raised verbs over nonraised verbs, but the no-inversion group should not.

5. Lardiere (1998, p. 364) notes, however, that this account is problematic for two reasons: (a) in the absence of English native-speaker data, it is hard to predict whether (and how) a heavy noun phrase shift would affect processing, and (b) the objects in the stimuli were not heavy and would have been ungrammatical in English.

6. With indefinite noun phrases, the negator and indefinite article fuse into the form geen "not+a" (e.g., Anne heeft geen boek gelezen "Anne has no book read"). The use of geen + object is highly preferred over the nonscrambled sentence (Anne heeft een boek niet gelezen). For a more detailed account of scrambling in Dutch and the associated scope differences see de Hoop (2003).

7. Kornfilt (1997) mentions a further use of değil, which is widely attested in colloquial language, but less so in written language: in constructions of the type in (22), the negative copula is placed after the verbal predicate, which bears tense suffixes but no agreement markers. Instead, the agreement markers are attached onto değil.

(22) (Ben) iş-im-i bırak-acak değil-im

(I) work-1sg-acc leave-fut not.be- $1 s g$

I shall not leave my job"

(Kornfilt, 1997, p. 125)

8. These levels correspond to the A1 and A2 levels of the European Framework of Reference, respectively. At the A1 level, learners "can understand and use familiar everyday expressions and very basic phrases aimed at the satisfaction of needs of a concrete type." At the A2 level, learners "can understand sentences and frequently used expressions related to areas of most immediate relevance" (Council of Europe, 2001, p. 124).

9. No influence of literacy was found. Seven out of all eight illiterate learners produced auxiliaries and thus fell into the more advanced group.

10. In the Berber variety spoken by the current learners (Tamazight), the negator also consists of a pre- and postverbal element ( $u r$ and $\check{s} a$ ). The basic word order of 
Verhagen: Verb placement in second language acquisition

Tamazight is VSO, but SVO is also used (Ouhalla, 1988). The following is an example of a negated sentence in Tamazight:

$\begin{array}{ll}\text { (23) Ur iffirq } & \text { ša } \\ \text { Neg exit.past.3ms } & \text { neg } \\ \text { "He didn't go out" } & \end{array}$

(Boumalk, 1996, p. 36)

11. The native speakers also performed the elicited imitation task, but the task was not demanding enough to lead to active reconstruction, because they produced very few changes to the stimuli items. Therefore, these data will not be considered further.

12. Collecting control data for the production tasks was felt necessary to check whether the production tasks actually elicited the intended structures from the participants. However, due to time limitations, only 10 native speakers carried out all production tasks.

13. At these schools, students are prepared for jobs that are based in manual or practical activities, traditionally nonacademic, and totally related to a specific trade. The current students were, among others, trained to become shop assistants or to work in a sewing factory.

14. Hameyer (1980) found that sentence length determines to what extent the task is reconstructive, as it correlates with the number of syntactic and semantic changes participants made. In most elicited imitation studies sentence length is discussed as a variable that needs to be considered in relation to a specific population and test design rather than as an absolute measure (Bley-Vroman \& Chaudron, 1994; Erlam, 2006; Munnich et al., 1994). In the current study, piloting was used to determine the optimal sentence length.

15. Perkins, Brutten, and Angelis (1986) found for L2 learners of English that these learners could imitate 26 sentences before they began to exhibit response arbitrariness. Therefore, the current L2 learners were presented with two sessions containing no more than 18 sentences each. Although three data points per condition may seem too few, Fujiki and Brinton (1983) showed that three repetitions provided reliable data for each participant.

16. This list contained all shared nouns and verbs in three frequency lists: a frequency list by Hulstijn and Hazenberg (for more information, cf. Hulstijn \& Hazenberg, 1996), containing 2,830 words, as well as two lists with the 2,000 most frequent nouns and verbs of Celex and Corpus Gesproken Nederlands "Corpus of Spoken Dutch."

17. None of the earlier sentence-matching studies reports the use of comprehension questions. Because the inclusion of such questions has proven useful in other psycholinguistic methods such as self-paced reading and eye tracking (Marinis, Roberts, Felsen. \& Clahsen, 2005; Roberts, Gullberg \& Indefrey, 2008), it was adopted for the current study.

18. As is common in this type of research, chi-square tests were conducted to see whether differences between the groups were significant. Note, however, that such tests may obscure within-group variation.

19. Some responses could not be analyzed because they were inaudible or because too many elements had been left out. This explains why the numbers in the third and fourth column do not always add up to the total number of stimuli sentences presented. 
Verhagen: Verb placement in second language acquisition

20. It seems difficult to explain why the Turkish learners left out hebben more often in the grammatical condition than in the ungrammatical condition. One could assume that hebben is easier to notice or process when it follows negation than when it precedes negation, but this is hard to reconcile with the finding that learners frequently changed NEG - AUX into AUX - NEG. One possibility, then, might be that the learners who left out hebben formed a different subgroup than the learners who changed NEG AUX into AUX - NEG. An analysis of the data suggests that this is not the case: in the Turkish -AUX group, where auxiliary omission was most frequent, most learners changed NEG - AUX into AUX - NEG and at the same time left out hebben in AUX NEG stimuli, but not NEG - AUX stimuli $(n=11)$. Smaller subgroups involved learners who changed NEG - AUX into AUX - NEG and left out hebben in NEG AUX stimuli $(n=3)$, and learners who produced omissions but no changes $(n=4)$. There was one learner who produced only changes and no omissions.

\section{REFERENCES}

Baumann, H., Nagengast, J., \& Wittenburg, P. (1992). A new experimental set-up, a tool for experimenting in the 90 s. Paper presented at the International Congress of Social Science Information Technology, Amsterdam.

Beck, M. (1998). L2 Acquisition and obligatory head-movement: English-speaking learners of German and the local impairment hypothesis. Studies in Second Language Acquisition, 20, 311-348.

Becker, A. (2005). The semantic knowledge base for the acquisition of negation and the acquisition of finiteness. In H. Hendriks (Ed.), The structure of learner varieties (pp. 263-314). New York: Mouton de Gruyter.

Bernini, G. (2003). The copula in learner Italian: Finiteness and verbal inflection. In C. Dimroth \& M. Starren (Eds.), Information structure, linguistic structure, and the dynamics of acquisition (pp. 159-185). Amsterdam: John Benjamins.

Bley-Vroman, R., \& Chaudron, C. (1994). Elicited imitation as a measure of second-language competence. In E. Tarone, S. Gass, \& A. Cohen (Eds.), Research methodology in second-language acquisition (pp. 245-253). Hillsdale, NJ: Erlbaum.

Bley-Vroman, R., \& Masterson, D. (1989). Reaction time as a supplement to grammaticality judgments in the investigation of second language learners' competence. University of Hawaii Working Papers in ESL, 8, 207-237.

Boumalk, A. (1996). La negation en berbère marocain. In S. Chaker \& D. Caubet (Eds.), La negation en berbère et en arabe maghrébin (pp. 35-48). Paris: L'Harmattan.

Cancino, H., Rosansky, E., \& Schuman, J. (1978). The acquisition of English negatives and interrogatives by native Spanish speakers. In H. Hatch (Ed.), Second language acquisition (pp. 207-230). Rowley, MA: Newbury House.

Chambers, S., \& Forster, F. (1975). Evidence for lexical access in a simultaneous matching task. Memory \& Cognition, 3, 549-559.

Chomsky, N. (1995). The minimalist program. Cambridge, MA: MIT Press.

Clahsen, H. (1983). Some more remarks on the acquisition of German negation. Journal of Child Language, 10, 465-469.

Clahsen, H. (1988). Critical phases of grammar development. A study of the acquisition of negation in children and adults. In P. Jordens \& J. Lalleman (Eds.), Language development (pp. 123-148). Dordrecht: Foris.

Clahsen, H., \& Felser, C. (2006). How native-like is non-native processing? Trends in Cognitive Sciences, 10, 560-570.

Council of Europe. (2001). A common European framework of reference for languages: Learning, teaching, assessment. Cambridge: Cambridge University Press.

Dahl, Ö. (1979). Typology of sentence negation. Linguistics, 17, 79-106.

de Hoop, H. (2003). Scrambling in Dutch: Optionality and optimality. In S. Karimi (Ed.), Word order and scrambling (pp. 201-216). Oxford: Blackwell. 
Verhagen: Verb placement in second language acquisition

Dimroth, C. (2002). Topics, assertions and additive words: How L2 learners get from information structure to target-language syntax. Linguistics, 40, 891-923.

Dimroth, C. (2005). The finite story [Animated movie]. Amsterdam: Max Planck Institute for Psycholinguistics.

Dimroth, C. (2008). German at different ages: Negation and finiteness in adult, adolescent and child learners. Language Learning, 58, 117-150.

Duffield, N., \& White, L. (1999). Assessing L2 knowledge of Spanish clitic placement: Converging methodologies. Second Language Research, 15, 133-160.

Duffield, N., White, L., Bruhn de Gravito, J., Montrul, S., \& Prévost, P. (2002). Clitic placement in L2 French: Evidence from sentence matching. Journal of Linguistics, 38, 487-525.

Ennaji, M. (2005). Multilingualism, cultural identity, and education in Morocco. New York: Springer. Epstein, S., Flynn, S., \& Martohardjono, G. (1996). Second language acquisition: Theoretical and experimental issues in contemporary research. Behavioral and Brain Sciences, 19, 677-758.

Erguvanl1-Taylan, E. (1984). The function of word order in Turkish grammar. Berkeley, CA: University of California Press.

Erlam, R. (2006). Elicited imitation as a measure of L2 implicit knowledge: An empirical validation study. Applied Linguistics, 27, 464-491.

Eubank, L. (1993/1994). On the transfer of parametric values in L2 development. Language Acquisition, 3, 183-208.

Eubank, L., \& Grace, S. (1996). Where's the mature language? Where's the native language? In A. Stringfellow, D. Cahana-Amitay, E. Hughes, \& A. Zukowski (Eds.), Proceedings of the 20th Annual Boston University Conference on Language Development (pp. 189-200). Somerville, MA: Cascadilla Press.

Ferreira, F., Christianson, K., \& Hollingworth, A. (2001). Misinterpretations of garden-path sentences: Implications for models of reanalysis. Journal of Psycholinguistic Research, 30, 3-20.

Ferreira, F., \& Patson, N. (2007). The "good enough" approach to language comprehension. Language and Linguistics Compass, 1, 71-83.

Freedman, S., \& Forster, K. (1985). The psychological status of overgenerated sentences. Cognition, 19, 101-131.

Fujiki, M., \& Brinton, B. (1983). Sampling reliability in elicited imitation. Journal of Speech and Hearing Disorders, 48, 85-89.

Gass, S. (2001). Sentence matching: A re-examination. Second Language Research, 17, 421-441.

Grondin, N., \& White, L. (1996). Functional categories in child L2 acquisition of French. Language Acquisition, 5, 1-34.

Grüter, T. (2005/2006). Another take on the L2 initial stage: Evidence from comprehension in L2 German. Language Acquisition, 13, 287-317.

Hameyer, K. (1980). Testing oral proficiency via elicited imitation. Revue de Phonétique Appliquée, $53,11-24$.

Hawkins, R. (2001). Second language syntax. A generative introduction. Oxford: Blackwell.

Haznedar, B. (1997). L2 acquisition by a Turkish speaking child: Evidence for L1 influence. In E. Hughes, M. Hughes, \& A. Greenhill (Eds.), Proceedings of the 21st Annual Boston University Conference on Language Development (pp. 245-256). Somerville, MA: Cascadilla Press.

Haznedar, B., \& Schwartz, B. (1997). Are there optional infinitives in child L2 acquisition? In E. Hughes, M. Hughes, \& A. Greenhill (Eds.), Proceedings of the 21st annual Boston University conference on language development (pp. 257-268). Somerville, MA: Cascadilla Press.

Harrell, R. (1962). A short reference grammar of Moroccan Arabic. Washington, DC: Georgetown University Press.

Horn, L. R. (1989). A natural history of negation. Chicago: University of Chicago Press.

Hulstijn, J., \& Hazenberg, S. (1996). Defining a minimal receptive second-language vocabulary for non-native university students: An empirical investigation. Applied Linguistics, 17, 145-163.

Jagtman, M. (1994). Computer-aided syntactic analysis on interlanguage data. Unpublished doctoral dissertation, Radboud University, Nijmegen.

Jansen, B., Lalleman, J., \& Muysken, P. (1981). The alternation hypothesis: Acquisition of Dutch word order by Turkish and Moroccan foreign workers. Language Learning, 31, 315-336.

Jordens, P. (2002). Finiteness in early child Dutch. Linguistics, 40, 687-766.

Jordens, P. (2004). Systematiek en dynamiek bij de verwerving van finietheid. Toegepaste Taalwetenschap in Artikelen, 71, 9-22. 
Verhagen: Verb placement in second language acquisition

Klein, W. (1998). Assertion and finiteness. In N. Dittmar \& Z. Penner (Eds.), Issues in the theory of language acquisition: Essays in honor of Jürgen Weissenborn (pp. 225-245). Bern: Lang.

Kornfilt, J. (1997). Turkish. New York: Routledge.

Krashen, S., \& Terrell, T. (1983). The natural approach: Language acquisition in the classroom. London: Prentice Hall Europe.

Lardiere, D. (1998). Dissociating syntax from morphology in a divergent L2 end-state grammar. Second Language Research, 14, 359-375.

Marinis, T., Roberts, L., Felser, C., \& Clahsen, H. (2005). Gaps in second language sentence processing. Studies in Second Language Acquisition, 27, 53-78.

Markman, B., Spilka, I., \& Tucker, G. (1975). The use of elicited imitation in search of an interim French grammar. Language Learning, 75, 31-41.

Meisel, J. (1983). Strategies of second language acquisition: More than one kind of simplification. In R. Andersen (Ed.), Pidginization and creolization as language acquisition (pp. 120-157). Rowley, MA: Newbury House.

Meisel, J. (1997). The acquisition of the syntax of negation in French and German: Contrasting first and second language development. Second Language Research, 13, 227-263.

Munnich, E., Flynn, S., \& Martohardjono, G. (1994). Elicited imitation and grammaticality judgment tasks: What they measure and how they relate to each other. In E. Tarone, S. Gass, \& A. Cohen (Eds.), Research methodology in second language acquisition (pp. 227-243). Hillsdale, NJ: Erlbaum.

Naiman, N. (1974). The use of elicited imitation in second language acquisition research. Working Papers on Bilingualism, 2, 1-37.

Ouhalla, J. (1988). The ayntax of head movement: A study of Berber. Unpublished doctoral dissertation, University College London.

Ouhalla, J. (1994). Verb movement and word order in Arabic. In D. Lightfoot \& N. Hornstein (Eds.), Verb movement (pp. 41-72). Cambridge: Cambridge University Press.

Parodi, T. (2000). Finiteness and verb placement in second language acquisition. Second Language Research, 16, 4, 355-381.

Perkins, K., Brutten, S., \& Angelis, P. (1986). Derivational complexity and item difficulty in a sentence repetition task. Language Learning, 36, 125-141.

Phillips, C. (1995). Syntax at age two: Crosslinguistic differences. MIT Papers on Language Processing and Acquisition, 26, 225-282.

Roberts, L., Gullberg, M., \& Indefrey, P. (2008). Online pronoun resolution in L2 discourse: L1 influence and general learner effects. Studies in Second Language Acquisition, 30, 333357.

Rohrbacher, B. (1994). The Germanic languages and the full paradigm: A theory of $V$ to I raising. Unpublished doctoral dissertation, University of Massachusetts.

Schwartz, B., \& Sprouse, R. (1996). L2 cognitive states and the full transfer/full access model. Second Language Research, 12, 40-72.

Tabor, W., Galantucci, B., \& Richardson, D. (2004). Effects of merely local syntactic coherence on sentence processing. Journal of Memory and Language, 50, 355-370.

Tura, S. (1981). "Yes, he hasn't" and a few other not's in Turkish. Proceedings of the Berkeley Linguistic Society, 7, 317-327.

Tomaselli, A., \& Schwartz, B. (1990). Analyzing the acquisition stages of negation in L2 German: Support for UG in adult SLA. Second Language Research, 61, 1-38.

Vainikka, A., \& Young-Scholten, M. (1996a). Gradual development of L2 phrase structure. Second Language Research, 12, 7-39.

Vainikka, A., \& Young-Scholten, M. (1996b). The earliest stages in adult L2 syntax: additional evidence from Romance speakers. Second Language Research, 12, 140-176.

Van de Craats, I., \& Van Hout, R. (2010). Dummy auxiliaries in the second language acquisition of Moroccan learners of Dutch: Form and function. Second Language Research, 26, 473-500.

Verrips, M., \& Weissenborn, J. (1992). Routes to verb placement in early French and German: The independence of finiteness and agreement. In J. Meisel (Ed.), The acquisition of verb placement (pp. 283-331). Dordrecht: Kluwer.

Vikner, S. (1995). Verb movement and expletive subjects in the Germanic languages. Oxford: Oxford University Press. 
Applied Psycholinguistics 32:4

Verhagen: Verb placement in second language acquisition

Vinther, T. (2002). Elicited-imitation: A brief overview. International Journal of Applied Linguistics, $12,54-73$.

Wexler, K. (1994). Optional infinitives, verb movement and the economy of derivation in child grammar. In D. Lightfoot \& N. Hornstein (Eds.), Verb movement (pp. 305-345). Cambridge: Cambridge University Press.

White, L. (1991). Adverb placement in second language acquisition: Some effects of positive and negative evidence in the classroom. Second Language Research, 7, 337-360.

White, L. (1992). Long and short movement in second language acquisition. Canadian Journal of Linguistics/Revue Canadienne de Linguistique, 37, 273-286. 